\title{
REVIEW
}

\section{Fungi in lake ecosystems}

\author{
Christian M. Wurzbacher ${ }^{1}$, Felix Bärlocher ${ }^{2}$, Hans-Peter Grossart ${ }^{1, *}$ \\ ${ }^{1}$ Leibniz Institute of Freshwater Ecology and Inland Fisheries, Alte Fischerhütte 2, 16775 Stechlin, Germany \\ ${ }^{2}$ Department of Biology, Mount Allison University, 63B York Street, Sackville, New Brunswick E4L 1G7, Canada
}

\begin{abstract}
This review highlights the presence and ecological roles of fungi in lakes, and aims to stimulate research in aquatic mycology. In the study of lentic systems, this field is an almost completely neglected topic and, if considered at all, has often been restricted to specific groups of fungi, such as yeasts, filamentous fungi (e.g. aquatic hyphomycetes), or phycomycetes (an obsolete taxonomic category that included various fungal and fungal-like organisms). We document that aquatic fungi are common in various lentic habitats. They play potentially crucial roles in nutrient and carbon cycling and interact with other organisms, thereby influencing food web dynamics. The development and application of molecular methods have greatly increased the potential for unraveling the biodiversity and ecological roles of fungi in lake ecosystems. We searched the literature for reports on all fungi occurring in lake ecosystems. The present study summarizes information on the highly diverse mycoflora in lake microhabitats and highlights the main processes they influence. We also point out ecological niches of fungi in lakes that have been examined only superficially or ignored completely. We demonstrate that we now have the methodology to perform systematic studies to finally fill in some of the large gaps in this field.
\end{abstract}

KEY WORDS: Aquatic fungi $\cdot$ Lakes $\cdot$ Ecology $\cdot$ Interactions $\cdot$ Biodegradation $\cdot$ Methodology $\cdot$ Food web Resale or republication not permitted without written consent of the publisher

\section{INTRODUCTION}

Water moulds have been known since the Middle Ages, and ichthyologists fear them as parasites of fishes and their spawn. In the middle of the nineteenth century, chlorophyll-free microplants with rhizoids and zoospores were discovered on several algae and substrates (Braun 1856). They were called phycomycetes, a now obsolete category that included Chytridiomycetes, Hyphochytridiomycetes, Plasmodiophoromycetes, Oomycetes, Zygomycetes, and Trichomycetes. In the $1940 \mathrm{~s}, \mathrm{C}$. T. Ingold isolated and described many filamentous fungi, whose spore morphologies were adapted to dispersal in running waters followed by attachment to plant detritus, such as leaves. They have become known as aquatic hyphomycetes or 'Ingoldian fungi'. At that time, phycomycetes were the focus of most investigators, including Ingold's former students H. Canter-Lund and J. W. G. Lund. Many publications addressed the biodiversity and ecology of zoosporic fungi, and Sparrow (1960) published keys to all known species, together with ecological data, in his monograph 'Aquatic Phycomycetes'. Later Sparrow assembled the ecological knowledge of all aquatic fungi in a comprehensive review (Sparrow 1968). A detailed view on lower aquatic fungi was later provided in Jones (1976). Interest switched to aquatic hyphomycetes in lotic systems once they were identified as major participants in the food web. Lake ecosystems, however, remained largely neglected. Further insights into biodiversity and ecology of higher aquatic fungi in general are found in Goh \& Hyde (1996), Wong et al. (1998), Shearer et al. (2007), and, most recently, Gleason et al. (2008) for lower fungi and Gulis et al. (2009) for littoral fungi. We also refer the interested reader to Jones (1976), Canter-Lund \& Lund (1995), and Sigee (2005).

\section{Evolution of fungi in aquatic habitats}

A major problem one encounters when reviewing literature on aquatic fungi is that often only one group is addressed and all others are neglected. For example, 
after several decades of intensive research on leaves decaying in streams, much is known about aquatic Hyphomycetes, and they are widely regarded as dominating this process. Recently, however, molecular methods have revealed an astonishing diversity of fungi belonging to other groups (Nikolcheva \& Bärlocher 2004), suggesting a hitherto unknown ecological role of these taxa. Similar serendipitous discoveries were made in pelagic environments and sediments of lakes (see 'Pelagic zone' and 'Profundal zone and sediment' sections below). The Kingdom Fungi was only recognized some $40 \mathrm{yr}$ ago, and its diversity is vastly understudied (only approximately $7 \%$ of total estimated species have been described; Mueller \& Schmit 2007). According to Shearer et al. (2007) there is an urgent need for better documentation of the numerous undescribed species, especially in aquatic habitats. Only recently has a consistent fungal tree of life been generated (Lutzoni et al. 2004, James et al. 2006), and it excludes several phylogenetic groups formerly considered fungi, e.g. Oomycetes and various slime molds. These groups will nevertheless be included in our review, as they often occupy similar niches to those occupied by true fungi (Sparrow 1968).

Based on their evolutionary history, fungi in aquatic habitats are either primarily (Chytridiomycetes) or secondarily adapted to life in water (aquatic hyphomycetes, yeasts). In addition, primarily terrestrial forms (various fungi imperfecti, endophytes) are found in lakes, suggesting that their occurrence is not necessarily restricted to a single habitat by stringent morphological or physiological adaptations. Like Oomycetes (fungus-like organisms belonging to the Kingdom Chromista), Chytridiomycetes (Kingdom Fungi) possess chemotactic, flagellated zoospores, which can disperse in the water column (Sparrow 1968). They are located at the base of the fungal phylogenetic tree, which means they had a window of 900 to 480 million years (Heckman et al. 2001) to potentially colonize and adapt to all aquatic habitats and niches. They may well be ubiquitous within freshwater ecosystems (as uniquely demonstrated in Sparrow 1960) (see Fig. 1) but have often been overlooked (Powell 1993, Canter-Lund \& Lund 1995) or misidentified, e.g. as flagellates (Lefèvre et al. 2007). In contrast, aquatic hyphomycetes and yeasts are secondary invaders of aquatic habitats and are polyphyletically scattered in the fungal tree. Aquatic hyphomycetes and other filamentous terrestrial forms generally need a solid substrate and use the water column only for dispersal of their propagules, whereas yeasts are potentially found everywhere including the pelagic zone.

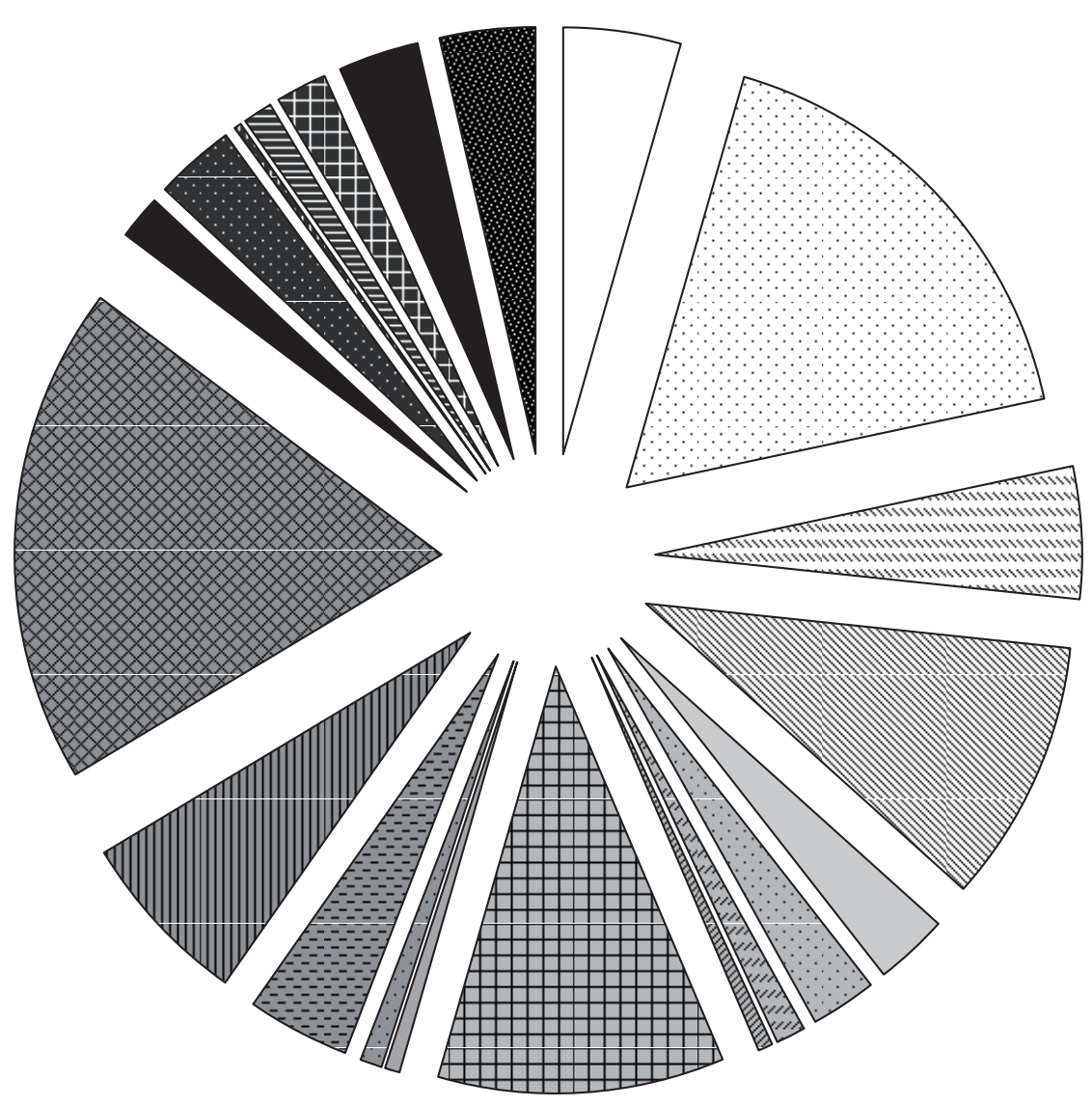

\begin{tabular}{|c|c|}
\hline$\square$ Cyanobacteria & B Brown Algae \\
\hline$\therefore$ Green Algae & D Red Algae \\
\hline Zygnematales & Phycomycetes \\
\hline $\mathbb{N}$ Desmids & Other fungi \\
\hline Characeae & Protozoa \\
\hline - Xanthophyceae & Trematoda \\
\hline Chrysophyceae & 三 Nematoda \\
\hline $\mathscr{Z}$ Dinophyceae & A Rotifera \\
\hline 田 Bacillariophyceae & Crustacea \\
\hline Cryptophyceae & Insecta \\
\hline
\end{tabular}

Euglenophyceae

Fig. 1. Algae and other aquatic organisms (661 species) on which at least one species of lower aquatic fungi has been found. The following substrates have been excluded: pollen, seeds, plants, twigs, fruits, exuviae, cellulose, chitin, keratin; after Sparrow (1960) 
Terrestrial fungi are often passively introduced into lakes in the form of high loads of fungal propagules via inflowing streams, rainwater, and wind (Smirnov 1964). However, it is often unclear whether such fungi, lacking typical morphological adaptations, are terrestrial or truly aquatic. For example, species of Aspergillus and Penicillium are among the most common fungal isolates from terrestrial, freshwater, and marine environments, even from deep-sea sediments. Some are active and partially adapted to aquatic habitats. Conversely, truly aquatic fungi have been found active in several terrestrial habitats. Park (1972) provides a useful characterization of such fungi based on their activity, ranging from indwellers (with constant to no activity) to transients (no activity). His main conclusion is that there may be no simple and exclusive division of microorganisms into aquatic and non-aquatic types.

Terrestrial filamentous fungi are the main decomposers and producers of humic matter, and play a dominant role in the remineralization of nitrogen. In aquatic systems, however, they cannot rely on their hyphal growth and have to compete with many other heterotrophs, especially prokaryotes. Since Bacteria and Archaea occur at high cell densities $\left(10^{5}\right.$ to $10^{7}$ cells ml ${ }^{-1}$ in open water and $10^{9}$ to $10^{11}$ cells $\mathrm{g}^{-1}$ in sediments), they rapidly take up labile dissolved organic matter (DOM) as soon as it becomes available. In contrast, cell numbers or biomasses of aquatic fungi are much lower in the open water or in sediments, and high abundances are probably restricted to particles such as litter. For example, yeast cells in the pelagic zone (as a counterpart to free-living bacteria) have an average annual density of 0.7 colony-forming units (CFU) $\mathrm{ml}^{-1}$ in a nonpolluted lake (Woollett \& Hedrick 1970), and 0 to $0.25 \mathrm{CFU} \mathrm{ml}^{-1}$ in Patagonian waters (Libkind et al. 2003), and there is no evidence that free-floating fungal colonies occur in the water column. This suggests that eukaryotic fungi have less of an impact than bacteria in aquatic systems unless (1) the microhabitat is relatively constant over time (d) - e.g. in stagnant water, biofilms, and on surfaces; in matrices or steep spatial gradients (e.g. litter) (Sampaio et al. 2007); on algae (Kagami et al. 2007); in aggregates and extracellular polysaccharides (Masters 1971)—, (2) the nutrient source is highly recalcitrant and/ or requires specific enzymes - e.g. polyaromatic hydrocarbons (MacGillivray \& Shiaris 1993, Giraud et al. 2001, Augustin 2003), humic matter (Claus \& Filip 1998), chitin (Reisert \& Fuller 1962), and lignocellulose (Fischer et al. 2006) (3) fungi participate in specialized interspecies relationships: mutualism (Gimmler 2001), commensalism (Lichtwardt 2004), parasitism (Whisler et al. 1975, Ibelings et al. 2004), and predation (Barron 1992).

In nature, more than one of the abovementioned conditions may apply and favor a fungal life-style char- acterized by hyphal nutrient absorption. The hyphal cell wall consists of multiple layers of different polysaccharides (Durán \& Nombela 2004), which render it very stable and highly absorbent. Incorporation of melanin further increases its stability and tolerance of various environmental stresses (reviewed in Nosanchuk \& Casadevall 2003). Not surprisingly, fungi are often found in disturbed areas with high anthropogenic loads (industrial and municipal wastes, sewage treatment plants) (see e.g. Cooke 1976, Weber et al. 2009); however, they also occur under ultraoligotrophic conditions, such as in a water distillation apparatus (reviewed in Wainwright 2005). Some fungi may use small airborne compounds to grow, which again suggests a highly effective nutrition acquisition strategy. There is even a suggestion that some fungi may be partially autotrophic, i.e. they gain energy from sources other than organic compounds, e.g. from ionizing radiation (Dadachova et al. 2007).

\section{Fungal occurrence in specific lake habitats}

Searching the literature for fungal occurrence or activity in lakes is like fishing in these lakes using the wrong bait. Most publications are widely dispersed among various biological disciplines, and fungi appear only on the fringes. Lakes are highly structured into different zones, and each zone can harbor specific animal, plant, and fungal communities. At the outset, and of particular relevance for fungi, it is important to distinguish between open-water habitats and shallow, highly structured lake zones that are dominated by macrophytes and periphyton, directly connected to terrestrial influences. Due to its greater supply of organic matter, the littoral zone is a hot spot for all kinds of fungi, whereas the pelagic zone harbors only highly specialized species or serves as a medium for the dispersal of propagules.

\section{Littoral zone}

The littoral area in lakes is a transition zone between terrestrial and aquatic habitats. It often merges into a marsh, a type of wetland subject to frequent or continuous flooding. It is a biodiversity hot spot and home to many aquatic and terrestrial fungi as well as a place where many energy transformation processes take place. Stony supralittoral areas support a highly diverse lichen flora specifically adapted to lake shores. The supralittoral zone can be further divided into subzones for lichens based on differential 'splash zones'. The occurrence of lichens also correlates with water pH and alkalinity (Gilbert \& Giavarini 2000). Sub- 
merged lichens are rarely found in lentic waters. They are amphibious and generally restricted to cold alpine lakes in zones with wave action (H. Thüs pers. comm.). However, very recently lichens were found in Lake Baikal, Russia, covering rock surfaces occasionally down to water depths of $7 \mathrm{~m}$ (Kulikova et al. 2008). In addition to lichens, zoosporic fungi and fungal-like organisms are found in supralittoral soils (Sparrow 1968 and references therein, Ali \& Abdel-Raheem 2003). 'Aero-aquatic' fungi form another group of mitosporic fungi adapted to frequent drying and wetting cycles (Webster \& Descals 1981). These fungi grow on plant detritus in water and mud at low oxygen levels but need air exposure for reproduction. Along dystrophic lake shores, the decomposition of sphagnum may be mediated by fungal organisms, which serve as a food source for arthropods (Smirnov 1961). The supralittoral and upper eulittoral zones serve as a habitat for emergent macrophytes, the major carbon source in these zones. Over 600 fungal species have been recorded from the common reed Phragmites australis (compiled by Gessner \& van Ryckegem 2003), and other emergent macrophytes have also been a rich source of fungal taxa (Ellis \& Ellis 1985). Studies of roots from other aquatic macrophytes revealed endomycorrhizae belonging to the Glomeromycota (an obligatory symbiotic fungal phylum) or dark septate endophytes in approximately $25 \%$ of all examined plant species (Beck-Nielsen \& Vindbaek Madsen 2001, Kai \& Zhiwei 2006) with some infection rates over $90 \%$ (Farmer 1985). Molecular techniques applied to Spartina alterniflora (Buchan et al. 2002, 2003, Torzilli et al. 2006) or to P. australis (Wirsel et al. 2001, Neubert et al. 2006) revealed a high fungal diversity. The diversity of endophytes in $P$. australis shoots alone was astonishingly high: by restriction fragment length polymorphisms (RFLP) of internal transcribed spacer (ITS) clones, Neubert et al. (2006) identified over 350 distinct operational taxonomic units (OTU). Total richness was extrapolated to be 750. Several of the sequenced OTUs represented undocumented fungal species.

Additionally, dead materials from macrophytes and allochthonous litter such as leaves, twigs, and wood accumulate in the littoral, and decomposition processes take place. Aquatic hyphomycetes have been found among other fungal groups at high abundances on leaf litter (Nilsson 1964, Casper 1965), and there is a naturally high fungal diversity on all kinds of dead macrophytes and plant litter including their aufwuchs in lakes (Casper 1965, Sparrow 1968, El-Hissy et al. 1990, Czeczuga 1991, Hyde \& Goh 1998, Wong et al. 1998, Cai et al. 2002, Luo et al. 2004, Orlowska et al. 2004, Czeczuga et al. 2005, Nechwatal et al. 2008). In addition to plant litter, there is a substantial influx of dead animals, insects, feathers, exuviae, fish-spawn, pollen, spores, and seeds. All these materials are readily colonized and degraded, often by zoosporic fungi (Sparrow 1960, 1968). In several studies, very diverse mycofloras were documented on every abovementioned substrate in several standing and running waters (see e.g. Czeczuga et al. 2002).

The benthic and periphytic habitats have not been systematically examined for the presence and roles of fungi, although it is generally taken for granted that fungi contribute to biofilm processes. The euphotic part of the benthic community is often dominated by large algal mats that are susceptible to parasitic and saprophytic fungi. When they become detached and form floating rafts, they are often heavily colonized by several fungi (Zopf 1884). These mats can also serve as surface for epiphytic predatory fungi, which trap nematodes, rotifera, and tardigrada (Sommerstorff 1911). Other fungal prey items known from terrestrial habitats are copepods, springtails, amoebae, bacteria, and other fungi (Barron 1992). Predatory fungi are common in shallow areas as part of the benthos in nearly all lake ecotypes from Antarctic lakes to sewage ponds (Cooke 1976, McInnes 2003, Hao et al. 2005). Direct observations of biofilms in sewage plants revealed that fungi make a significant contribution to trickling filters (Cooke 1976), and recent molecular and phospholipid fatty acids (PFLA) analyses revealed fungal residents in a living microbial mat (Cantrell et al. 2006). The appearance of fungi in biofilms is also supported by considerations on biogenic mineral transformations (Gall et al. 1994, Gadd 2007).

In the benthic zone there is also a stable population of mainly trichomycete endosymbionts in the guts of saprotrophic and herbivore aquatic arthropods (e.g. in chironomids) (see Lichtwardt 2004). Interestingly, in a recent mesocosm study with extremely high zooplankton numbers, Zygomycetes related to Entomophthorales represented $14 \%$ of all eukaryotic clones from cells in the size fraction 0.2 to $5 \mu \mathrm{m}$ (Lepère et al. 2007). This raises the possibility of a currently unknown role of this group in zooplankton populations.

\section{Pelagic zone}

Fungi of the genus Coelomomyces (Blastocladiomycota) have a life cycle alternating between the littoral and pelagic zones. They are all obligate endoparasites (Sparrow 1960) with 2 alternate hosts: a member of the Diptera, e.g. midge or mosquito larvae, and a planktonic copepod (Whisler et al. 1975). The parasitic lifestyle is common in the pelagic zone (Sparrow 1968, Gleason et al. 2008), where phytoplankton and zooplankton are a main food source. However, most pela- 
gic fungi are likely facultative parasites or saprotrophs (Sparrow 1960) that quickly exploit any opportunity to scavenge nutrients. The dominant planktonic fungi are zoosporic chytrids. They have adapted to the pelagic life by actively swimming between substrates. They compensate for their losses by producing large numbers of asexual spores and by forming resting spores.

These fungi (most likely including the novel LKM11 clade) (van Hannen et al. 1999) have long been recognized as prominent members of plankton communities in lakes (Sparrow 1960), and several reviews and book chapters have explained their role as parasites and their influence on algal succession (Sparrow 1960, Masters 1976, van Donk \& Bruning 1992, 1995, Canter-Lund \& Lund 1995, Ibelings et al. 2004, Sigee 2005, Kagami et al. 2007). Most studies focused on the diatom Asterionella formosa and its parasite Zygorhizidium spp. The genetic diversity of the host provides some protection against fungal infections and is an interesting model system for the Red Queen hypothesis (de Bruin et al. 2008). Microscopical studies have documented the seasonal occurrence of fungal parasites and their dependence on phytoplankton densities throughout the year (van Donk \& Ringelberg 1983, Holfeld 1998). The same pattern was shown for fungal OTUs, which were most numerous when chlorophyll a ( $\mathrm{chl}$ a) concentration reached its maximum (Lepère et al. 2006). Chytridiomycetes can be highly substrate-, alga-, or cell-stage specific, and they feature a set of exoenzymes allowing them to attack the most common polymers in the pelagic zone. However, due to their short generation times, their appearance is sporadic and patchy (Sparrow 1968, Masters 1976) and strongly dependent on environmental factors such as substrate density, light, temperature, and oxygen (Masters 1976, van Donk \& Bruning 1995, Holfeld 1998, Ibelings et al. 2004). Under certain circumstances, e.g. during an algal bloom, a mass development of one fungal species is observed and is often followed by its complete disappearance (Alster \& Zohary 2007). This interaction is not necessarily parasitic (Alster \& Zohary 2007), and the question of whether the collapse of the algal bloom is caused by the fungus cannot be answered in situ simply by tracking the 2 populations. Canter-Lund \& Lund (1995) extensively studied planktonic fungi on and in algae and give a good overview on algal-associated fungi.

The fungal flora on zooplankton is less diverse than that on algae (Ebert 2005, Johnson et al. 2006), because this niche seems to be mostly occupied by Oomycete species (Kingdom Chromista) (Sparrow 1968, Miao \& Nauwerck 1999). Zooplankton carcasses and exuviae form part of planktonic aggregates known as lake snow and are potential fungal habitats. These aggregates provide surfaces that are readily colonized. Fungi may play a role in decomposing zooplankton carcasses (Tang et al. 2006), and we found them colo- nizing exuviae and algal aggregates in the water column, sometimes at high abundance (Fig. 2). Aggregates may slowly sink to the lake bottom, where oxygen becomes more and more depleted. Much less is known about these anoxic lake water layers. Rosa et al. (1995) described a shift in yeast isolates presumably due to oxygen limitation, resulting in a decrease of aerobic species that may dominate in surface waters (Ahearn et al. 1968). Compared to the oxic epilimnion, fungal diversity in the oxicline itself can occasionally still be very high (Lefèvre et al. 2007), but to date no evidence for fungal organisms in the suboxic hypolimnion has been found (see e.g. Slapeta et al. 2005).

Filamentous fungi are thought to be absent in open water, which serves as an important dispersal medium for their propagules. The main representatives of higher fungi in open water are unicellular yeasts. Their potential to divide relies on access to nutrients in their immediate microenvironment. In pelagic water, even in marine systems, there is a stable population of yeasts at relatively low densities (Ahearn et al. 1968). For many years it was assumed that yeasts are transients washed in from the phylloplane or the littoral zone, but there is now clear evidence for their more or less permanent residence in open water. In addition to Cryptococcus sp., several red and black yeast species occur in lake surface water (van Uden \& Ahearn 1963, Woollett \& Hedrick 1970, Slavikova et al. 1992, Rosa et al. 1995, Libkind et al. 2003, Lefèvre et al. 2007), and their production of photoprotective compounds is thought to be one of their adaptations as residents of surface waters (Libkind et al. 2006). The yeast cell number correlates with the trophic status of the water body, ranging from oligotrophic to hypertrophic, and varies between 0.5 and $47 \mathrm{CFU} \mathrm{ml}^{-1}$ (annual averages) (Woollett \& Hedrick 1970). Selected species can be used as bioindicators for several kinds of anthropogenic pollution in aquatic environments (Hagler 2006 and references therein). However, species composition and abundance exhibit a pronounced patchiness between samples as well as between water depths (van Uden \& Ahearn 1963, Hedrick et al. 1964, Medeiros et al. 2008). High numbers of yeasts have also been found at greater depth and close to the lake bottom (Hedrick et al. 1964, Hedrick \& Soyugenc 1967). However, the specific lake conditions that favor their growth are still unknown.

\section{Profundal zone and sediment}

Wong et al. (1998) addressed the question whether fungal residents can be found at the lake bottom. Plating sediment samples yields fungal colonies (Collins \& Willoughby 1962, Tong et al. 2005), but it is often diffi- 

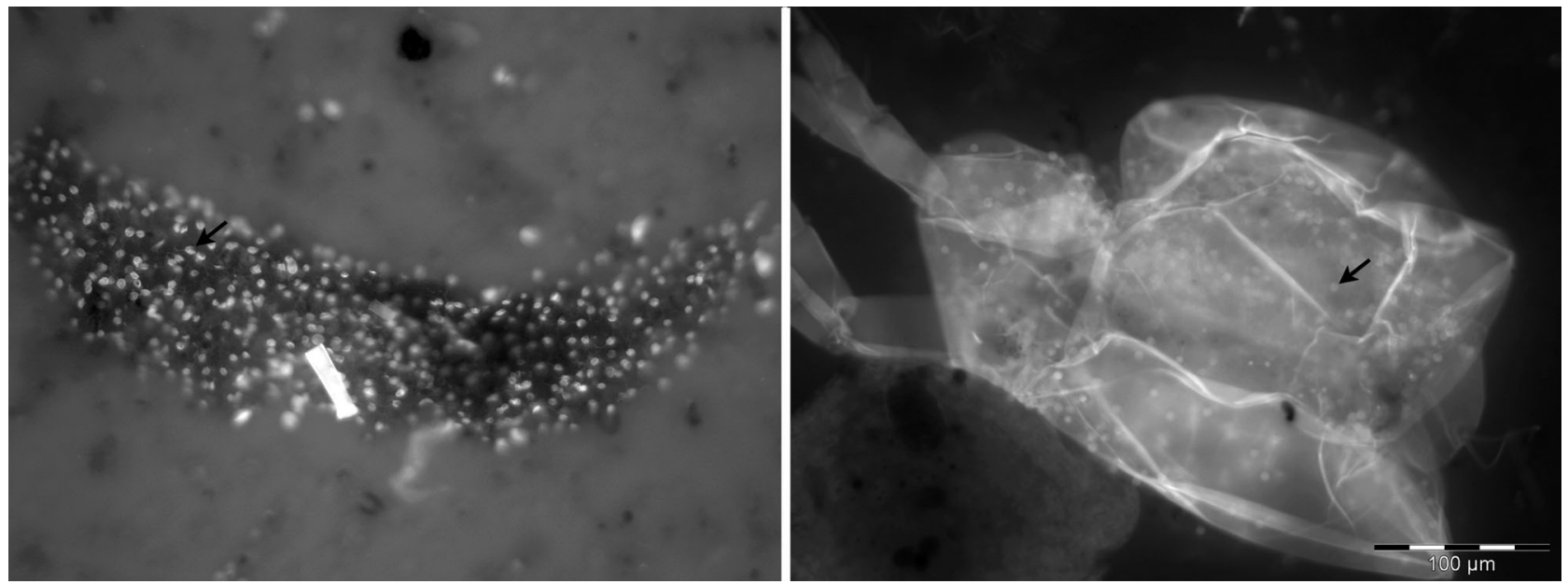

Fig. 2. Fungi on aggregates: planktonic aggregate (left) and zooplankton exuviae (right) in a pelagic lake sample heavily colonized by chitridious fungi (arrows) stained by the fluorescent brightener Calcofluor White

cult to determine their origin or even to identify them based on morphology (Collins \& Willoughby 1962, Tubaki 1973). Sediments serve as seedbank for resting spores of not only aquatic fungi but also of various terrestrial species. In the upper sediment layers, the response to antibiotic addition suggested a possible heterotrophic fungal activity in this habitat (Flegler et al. 1974). Oxygen, if present, is restricted to the uppermost $\mathrm{cm}$ of lake sediments. Fungi are generally thought to be aerophilic, but several species from all fungal phyla can withstand or remain active under anoxic conditions (Scupham et al. 2006). In sewage plants, the 2 fungal groups typical for the pelagic zone (see section 'Pelagic zone' above) occur in anoxic sites and can grow fermentatively: the Chytridiomycetes (Gleason 1976) and the yeasts (Cooke \& Matsuura 1963). Active chytrids were found parasitizing algal resting spores (Canter \& Heany 1984, Canter-Lund \& Lund 1995), and, more recently, PFLA analysis demonstrated fungal presence (dominating among eukaryotes) in the sediment (Goedkoop et al. 2005, Widenfalk et al. 2008). Ergosterol measurements estimated fungal biomass at $659 \mu \mathrm{g} \mathrm{C} \mathrm{g}^{-1}$ dry wt (Goedkoop et al. 2005). Many lake sediments connect with an aquifer through the interstitial. Aquifers seem to be a natural habitat for fungi (Ekendahl et al. 2003, Krauss et al. 2005), with an often astonishingly high diversity of yeasts and lower fungi (Brad et al. 2008). Hence, aquifers are potentially important for dispersal of fungal propagules between limnetic systems and should be kept in mind.

Near the lake margin the fungal community in the sediment is enriched by littoral species (Collins \& Willoughby 1962, Sparrow 1968, Ali \& Abdel-Raheem 2003). In 2 studies, clone libraries from lake and pond sediments revealed that fungi from freshwater and even brackish sediments are the most diverse eukaryotic group in these habitats (Dawson \& Pace 2002, Luo et al. 2005). Clones from pond sediments belonged primarily to Chytrids and yeasts (Slapeta et al. 2005). Another study from a similar habitat yielded almost exclusively sequences from the LKM11 clade (Luo et al. 2005). However, these studies were based on just 4 random samples from sediments in very small ponds with unknown environmental conditions (Luo et al. 2005, Slapeta et al. 2005). Hence, these data are preliminary but should encourage limnologists and microbiologists to pursue more detailed investigations. Overall, knowledge on fungi in lake sediments is very scarce, and there is a great need for more thorough and systematic studies.

\section{Fungi in different lake ecotypes}

In general, a low $\mathrm{pH}$ seems to favor certain fungal strains over bacteria. In a mine drainage biofilm, Eurotiomycetes and Dothideomycetes were found (Baker et al. 2004), and in acid mine lakes, the gut contents of chironomid larvae feeding as benthic collectors consisted primarily of fungi and bacteria (Rodrigues 2001). No systematic studies are available on benthic or pelagic fungi, although the presence of such fungi is obvious and well recognized (Gross \& Robbins 2000, Russo et al. 2008). Most dystrophic lakes in boreal regions or peatlands exhibit a naturally acidic $\mathrm{pH}$. Sparrow (1968) described bogs as one of the richest sources of bizarre types of chytrids. Peatland itself was recognized as a source for diverse fungal species (see e.g. Thormann 2006, Thormann et al. 2007, Artz et al. 2007), yet no systematic mycological studies have been conducted on bog lakes. The situation is even worse for al- 
kaline lakes. In the alkaline and saline Mono Lake (California), no fungi could be isolated from littoral water samples by plating (Steiman et al. 2004), but, to our knowledge, this is the only published survey. From saline lakes, halotolerant black yeasts and other species could be isolated regularly (Mallea 1992, Zalar et al. 1999, Butinar et al. 2005, Zalar et al. 2005, Cantrell et al. 2006), and some of them are now considered indigenous (Gunde-Cimerman et al. 2000). There are 2 startling reports from saline lakes: first, the discovery of filamentous fungi as active members of a saline microbial mat, demonstrated by PFLA and genetic analysis (Cantrell et al. 2006) and second, the appearance of lower fungi (Zygomycota and Chytridiomycota) in clone libraries from the anoxic sediment of Lake Namako-ike, Japan (Takishita et al. 2007). Both habitats deserve further study as potential fungal habitats.

\section{ECOLOGICAL ROLE OF FUNGI IN LAKE ECOSYSTEMS}

The ecology of fungi is structured by responses to the abiotic environment and interactions with other biota, which can lead to very successful, permanent associations, as is the case with lichens. Obligate biotic interactions already occur in the basal fungal phylum of the Chytridiomycota, whose members often depend on living or dead host materials. Table S1 in the supplement (available at: www.int-res.com/articles/ suppl/a059p125_app.pdf) gives a comprehensive overview on the diverse interactions of aquatic fungi.

\section{Decomposition process of particulate organic matter (POM)}

In terrestrial ecosystems, fungi are widely accepted as the dominant decomposers of plant matter, especially of highly recalcitrant lignocellulosic fibers. This is also true for lotic systems, and fungi introduce allochthonous leaf litter compounds into the food web of streams. Current knowledge of fungal ecology in lakes, however, is very rudimentary, with only a few studies having examined fungi on allochthonous leaf litter in lakes (Nilsson 1964, Casper 1965, Mishra \& Tiwari 1983, Baldy et al. 2002, Pabst et al. 2008). Depending largely on lake size and on the surrounding vegetation, allochthonous leaf litter carbon may contribute the equivalent of up to $10 \%$ of phytoplankton production in small lakes (Gasith \& Hasler 1976). In a medium sized lake (425 ha), leaf litter carbon input was estimated as $3 \%$ of the phytoplankton production (Casper et al. 1985). If most of the allochthonous leaf litter is deposited within $10 \mathrm{~m}$ of the shoreline (Hanlon
1981), it can become a main energy source for the food web in that littoral zone. For example, in small litter accumulating bays of Lake Stechlin, Germany, values of heterotrophic activity 20- to 100-fold higher than in the pelagic zone could be observed (Babenzien \& Babenzien 1985), and if we calculate the mean leaf litter carbon input for the first $10 \mathrm{~m}$ from the shoreline of Lake Stechlin, it accounts for $70 \%$ of the phytoplankton production. Not considered here are submerged and emerged macrophytes, whose contribution to lake metabolism can be substantial and which serve as deliverers of POM in the littoral zone (see 'Reed and macrophytes decomposition', below). This littoral POM can be subdivided into coarse particulate organic matter (CPOM) and readily dispersable fine particulate organic matter (FPOM), which serve as food for consumers in the littoral and pelagic zones (Preston et al. 2008) (see also Fig. 3). In oxygen-rich, wave-impacted zones, litter is colonized and conditioned by fungi and mechanically disintegrated by invertebrates (primarily by shredders and scrapers) and wave action (Baldy et al. 2002, Bohman 2005, Pabst et al. 2008). In contrast, litter deposited in sheltered areas decomposes under low oxygen conditions. This shifts the community to more anaerotolerant fungi (e.g. aero-aquatic hyphomycetes, yeasts), resulting in a lower decomposition rate (Chergui \& Pattee 1990, Baldy et al. 2002, Medeiros et al. 2009). Consequently, the decomposition of allochthonous POM largely depends on the lake shape, the extent of the littoral zones, and its exposure to wind. Which fungal groups are involved in the various scenarios still remains a mystery.

\section{Reed and macrophytes decomposition}

Marshes and shallow littoral zones have long been recognized as being among the most productive ecosystems (Westlake 1963, Mitsch \& Gosselink 2000). Production is dominated by genera such as Typha, Phragmites, Scirpus and Spartina (Gessner et al. 2007). The contribution of such vascular plant remains to energy flow in lakes depends on the extent and depth of littoral and transitional zones. In a global survey of standing water bodies, Wetzel (1990) demonstrated that most lakes are small $\left(<1 \mathrm{~km}^{2}\right.$ surface area) and shallow ( $<10 \mathrm{~m}$ mean depth). The ratios of perimeter to area and area to volume are high, thus increasing the importance of coupling between different habitat types (Schindler \& Scheuerell 2002). In the few documented cases, the contribution of vascular plant remains to lake metabolism has ranged between 10 and $75 \%$ (Webster \& Benfield 1986).

Consumption of living macrophytes is usually minimal, and the bulk of the primary production enters the 


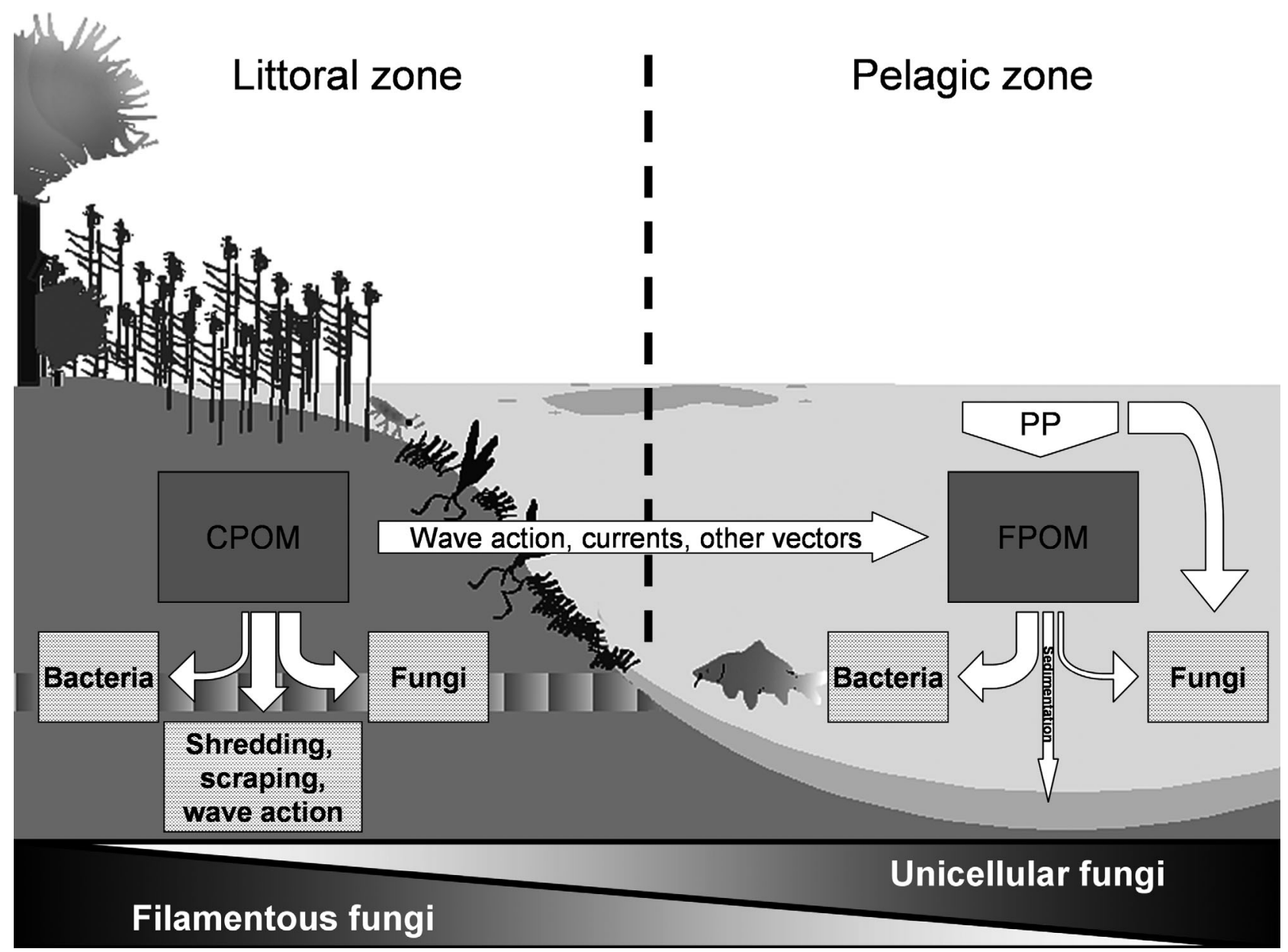

Fig. 3. Distribution and transformation processes of particulate organic matter (POM) in lake ecosystems, integrating different fungal morphotypes corresponding to littoral and pelagic zones. Arrows indicate the remineralization process of POM; PP (primary producers) are directly linked to aquatic fungi due to parasitism (see also 'Inner pelagic recirculation of nutrients: fungi as part of the microbial loop'). CPOM: coarse POM

detrital (non-living) carbon pool (Teal 1962, Newell 1993). Decomposition of detritus is initiated by microorganisms. Early studies of this process adopted the approach pioneered by terrestrial ecologists (e.g. Falconer et al. 1933, Luni 1933): plant material was collected and dried, and preweighed portions were incubated in containers, most commonly litter bags with variable mesh sizes. Periodically, some litter bags were recovered, the remaining detrital mass was determined, and chemical analyses were performed (e.g. Mason \& Bryant 1975, Godshalk \& Wetzel 1978, Morris \& Lajtha 1986; for review see Brinson et al. 1981). Decomposition under these conditions deviates from the natural process, and some of these modifications profoundly influence its course (Bärlocher 1997). Emergent macrophytes typically do not abscise leaves or stems. A substantial proportion of the biomass remains attached after senescence, and decomposition is initiated while leaves are still exposed to the air. Davis
\& van der Valk (1978, p. 663) emphasized that 'any study of emergent macrophyte decomposition ... must recognize the fact that the processes involved begin in an aerial environment and conclude in an aquatic environment'. Or, as Newell (1993, p. 307) put it, decomposition is initiated in a 'standing-dead' state. When Spartina alterniflora leaves were dried and submerged in litter bags or ground to a powder, bacteria dominated microbial biomass, and fungi were believed to play a negligible role (Benner et al. 1984, 1986, Moran \& Hodson 1990). This clearly contradicted microscopic examinations of naturally collected leaves, which revealed a high density of fungal reproductive structures in the form of ascoma (Newell \& Hicks 1982). Newell \& Fallon (1989) and Newell et al. (1989) solved this apparent paradox using a simple but ingenious technique. They tagged individual $S$. alterniflora leaves with electrical cable ties and compared their fate to that of dried leaves in submerged litter bags. 
When decomposition proceeded under more natural conditions (in a standing-dead state), the biomass of fungi greatly exceeded that of bacteria. These hugely influential papers emphasized the need for careful consideration of the prevailing conditions during decay (Newell 1993, 1996). While most of the early work was done in saltmarshes, the same principle applies to freshwater marshes and to the littoral zones of lakes. Newell et al. (1995) showed that in the Okefenokee Swamp, Georgia) fungal production greatly exceeded bacterial production on leaves of Carex walteriana decaying naturally in an upright, aerial position. As leaves fall and break into particles, there was a trend toward bacterial dominance.

Aerial macrophyte detritus has long been known to support a diverse community of terrestrial Ascomycetes and anamorphic fungi, which changes in a predictable manner when the substrate is submerged (Pugh \& Mulder 1971, Apinis et al. 1972a,b, Ellis \& Ellis 1985). Fungi on aerial macrophyte structures have clearly adapted to the rigors of their environment by a high xerotolerance. Kuehn et al. $(1999,2004)$ demonstrated a rapid positive response of fungal respiration to humidity, which fluctuates on a daily basis. Fungi on the emergent macrophyte Juncus effusus adjusted their concentrations of osmoregulatory polyols and trehalose to plant litter water potential (Kuehn et al. 1998). Ecologists ignored the first aerial phase and concentrated on submerged litter bags to follow decomposition (Polunin 1984). By tagging individual leaves, Bärlocher \& Biddiscombe (1996) showed that decomposition of Typha latifolia leaves begins well before the end of the growing season, and that most senescent and dead leaves lose weight while still attached and exposed to the air. Some leaves remained upright and attached throughout the winter, and 10 to $20 \%$ were still in that state 1 yr later, indicating a very prolonged aerial phase. Ergosterol levels (an indicator of fungal biomass) were up to $6 \times$ greater in naturally decaying aerial leaves than in predried leaves submerged in litter bags. In recent years, several researchers have studied decomposition of emergent macrophyte detritus under more natural conditions, i.e. while leaves or stems were still exposed to the air (for review see Kuehn 2008). The main emphasis has been on comparing biomasses and productivities of fungi and bacteria. Only a few studies have investigated the timing and dynamics of this transition (e.g. Newell \& Fallon 1989, Newell et al. 1989, Bärlocher \& Biddiscombe 1996, Gessner et al. 1996, Samiaji \& Bärlocher 1996). However, a number of studies consistently demonstrated that in the initial aerial phase of macrophytes in marine or freshwater marshes, fungal biomass and production typically exceed those of bacteria by a ratio of at least 9:1 (for reviews see Gessner et al. 1997, 2007, Kuehn 2008). There are consistent spa- tial (e.g. tip vs. basis of leaves, stems), temporal (senescent vs. dead), and substrate-specific (e.g., leaves vs. stems) differences in these ratios (Kuehn 2008). When standing plant litter of $J$. effusus was submerged, microbial biomass and production declined, but fungal decomposers remained dominant (Kuehn et al. 2000). Similarly, Mille-Lindblom et al. (2006a) found higher ergosterol levels on aerial than in naturally submerged parts of Phragmites australis, Schoenoplectus lacustris, and Nuphar lutea in 10 Swedish lakes. Litter properties explained $78 \%$ of the variation in microbial variables, while lake water chemistry accounted for $20 \%$. As in similar studies, it must be remembered that ergosterolbased methods only capture 'higher' fungi and miss the contributions of other fungal and fungus-like groups.

Fungi and bacteria clearly share a common substrate, and their close proximity can lead to synergistic or antagonistic interactions (Bengtsson 1992, MilleLindblom et al. 2006b). Antagonistic interactions appear to be based on interference competition involving allelochemicals, which may play a decisive role in the early stages of colonization. Howe \& Suberkropp (1993) described mycoparasitism on aquatic hyphomycetes by the fungus Crucella subtilis. Synergistic effects add to fungal capacities of attacking plant polymers such as lignin, cellulose, and hemicelluloses (Romani et al. 2006). Potential functional diversity, however, also exists at the intraspecific level. Several Ascomycetes involved in the decay of Spartina alterniflora leaves yielded multiple laccase types, as characterized by amplification from genomic DNA (Lyons et al. 2003). It is currently unknown whether multiple intraspecies laccases perform the same function or whether they have different substrate specificities and kinetics. Either way, fungi provide resources that bacteria cannot acquire on their own, most likely intermediate decomposition products released by fungi. Similar mechanisms have also been suggested for the relationships among different fungal species (Bärlocher \& Kendrick 1974) and between fungi and leafeating invertebrates (Bärlocher \& Porter 1986). The net effect of interfungal relationships can vary with species and abiotic conditions (for review see Pascoal \& Cássio 2008).

The initial phase of decomposition is often dominated by leaching (Bärlocher 1997), which is the abiotic loss of soluble ions and molecules from plant detritus and essentially completed within 1 to $2 \mathrm{~d}$. The release of dissolved organic compounds (DOM), however, can continue for weeks, partly maintained by the exoenzymatic release of polymer subunits. The formation and composition of these solutes is strongly influenced by the microbial community (Fischer et al. 2006). Bacteria actively remove low molecular weight DOM and high molecular weight DOM accumulates. 
Leaf-degrading fungi, on the other hand, promoted the accumulation of intermediate molecular weight DOM and are suppressed by bacteria (Fischer et al. 2006). Some studies have recorded distinct fungal successions during stages of decomposition (Pugh \& Mulder 1971, van Ryckegem et al. 2007). Based on microscopic observation of reproductive structures, the initial phase was generally dominated by common phylloplane hyphomycetes and coelomycetes such as Aureobasidium, Cladosporium, Alternaria, and Phoma. At later stages, Ascomycetes and Basidiomycetes became more common, with dominance patterns showing spatial differentiation (e.g. leaf blades vs. leaf sheaths, nodes, or internodes). Only a few studies have applied molecular techniques such as terminal restriction fragment length polymorphism (T-RFLP) or internal transcribed spacer (ITS) clone libraries to examine fungal communities on emergent macrophytes and the results were generally in agreement with those based on traditional methods (Buchan et al. 2002, 2003, Torzilli et al. 2006) but yielded greater diversity estimates. Large numbers of diverse taxa, many of them from uncultured species, are documented with molecular approaches (for example on detritus from leaves in freshwater streams or sediments) (Bärlocher et al. 2008, Seena et al. 2008). Generally, most of the OTUs are quite rare. On Phragmites australis, only 11 out of 350 OTUs occurred at a frequency of $>2 \%$ (Neubert et al. 2006). The significance of the many rare taxa is unknown. Are they simply transients? Are they waiting in the wings, ready to spring into action when the current dominants decline? This may provide some 'insurance' for maintaining ecological functions (portfolio effect) (Yachi \& Loreau 1999).

Much less work has been done on submerged plants. Czeczuga et al. (2005) examined dead and submerged fragments from 22 plant species in a spring, a river, and a pond. Fungal identification was by microscopic examination of antheridia and oogonia of zoosporic fungi and conidiophores and conidia of hyphomycetes. In total, 99 distinct species belonging to the Chytridiomycetes, Oomycetes, Zygomycetes, and Hyphomycetes were observed in the pond. Submerged plants were also a habitat for actinomycetes, which are potential competitors, and Wohl \& McArthur (1998) isolated 32 distinct strains from submersed fragments of several macrophytes. Actinomycetes were the dominant chitinoclastic microorganisms on crayfish exoskeletons in streams (Aumen 1980). The presence of an actinomycete inhibited growth by a true fungus, but a similar effect was found for a chitinless oomycete (Wohl \& McArthur 2001). The effect of Actinomycetes on various hydrolytic enzymes was more variable: depending on enzyme and strains, both stimulation and inhibition were observed. The few reports on aquatic Actinomycetes (e.g. Willoughby 1969, Cross 1981, Gavrishova 1981) mostly deal with their presence in littoral zones of reservoirs. More recently, the objective has been to discover novel enzymes and metabolites from these organisms (Takizawa et al. 1993, Jiang \& Xu 1996). The decomposition of submerged or floating macrophytes as well as other submerged plant detritus is still not satisfactorily explained, and questions remain concerning their influence on the detrital food web of the littoral zone and its dynamics. Fish exclusion experiments, for example, had a cascading effect down to fungal biomass in reed litter packs, where the fungal biomass suddenly increased by $43 \%$, after exclusion of large predatory fishes (Mancinelli et al. 2002). This fish exclusion prevented a trophic cascade only in summer but not in winter, when predatory invertebrates largely replaced fish (Mancinelli et al. 2007).

\section{Inner pelagic recirculation of nutrients: fungi as part of the microbial loop}

Fungi, as heterotrophic microbiota, are links in the microbial food web, transferring nutrients directly and indirectly to other trophic levels. The inclusion of zoosporic fungi in food web fluxes was first proposed by Sigee (2005). The parasitic fungi support a direct link between large 'inedible' algae (such as Asterionella) and filter-feeding zooplankton (such as Daphnia) (Kagami et al. 2004). Kagami et al. (2007) termed it later 'mycoloop'. Lefèvre et al. (2008) proposed a slightly modified food web scheme involving heterotrophic flagellates $(\mathrm{HF})$, in which they included fungal zoospores. They proposed a minor top-down influence of $\mathrm{HF}$ on bacteria but emphasized the mycoloop pathway: the utilization of nutrients from sinking or living large algae through HFs as a high quality nutrient source (Kagami et al. 2004). Gleason et al. (2008) proposed the inclusion of (1) saprophytic fungi as a further remineralization pathway in aquatic food webs based on all kinds of POM (dead phytoplankton, leaves, pollen, insects and crustacean exoskeletons, cadavers, and other detritus) that might be solubilized, and (2) the potential use of dissolved inorganic compounds (similar to bacteria) as seen in cell cultures. As expected, planktonic fungi are closely associated with the major pelagic surfaces, i.e. all types of aquatic organisms (Fig. 1) and most likely lake snow (Fig. 2). During sinking, bacteria actively colonize these organic aggregates, leading to DOM and nutrient release into the surrounding water. In contrast to bacteria, and due to their strong competition in the open water, fungi strictly depend on surfaces or steep gradients to settle (see 'Introduction'), e.g. lake snow aggre- 
gates. The use of inorganic compounds may then complement nutrient acquisition. In summary, fungi are not separated from, but are an integral part of, the microbial loop (as indicated in Fig. 3). We are just beginning to understand the influence of aquatic fungi on the food web, and several important questions emerge: What is the role of pelagic yeasts? What role do fungi play in the diet of protozoa, the 'natural enemies of the fungus' (Sparrow 1960)? What is the trophic role of fungi colonizing small 'edible' algae? Is there a direct link between fungi and heterotrophic bacteria (Soeder \& Maiweg 1969, Willoughby 1983)? What are the rates of flux between the various links?

\section{Fungal mediated transformation processes}

There is a long tradition of discharging domestic and industrial effluents into rivers. These effluents are often carried downstream to the next lake (Hynes 1971). Fungal biochemical transformations of nutrients and toxins in these effluents are of local and global relevance and often affect other organisms and the mobility of toxic substances. They are therefore of considerable ecological relevance for aquatic food webs. In many fundamental biogeochemical processes fungi play a pivotal role (e.g. Gall et al. 1994, Venrecchia 2000, Gadd 2006, Kolo et al. 2007), including organic and inorganic transformations and element cycling, rock and mineral transformations, mycogenic mineral formation, fungal-clay interactions, and metal-fungal interactions. Since aquatic fungi possess extremely diverse enzymatic capabilities (Zemek et al. 1985, Adrio \& Demain 2003, Rosa \& Gabor 2006) including the ability to degrade natural and anthropogenic polymers (see e.g. Abdullah \& Taj-Aldeen 1989), we will only give a few examples on specific processes of particular importance for lake ecosystems.

\section{Oxidation of $\mathrm{Mn}$}

Enzymatic oxidation of $\mathrm{Mn}(\mathrm{II})$ produces insoluble $\mathrm{Mn}(\mathrm{III}, \mathrm{IV})$ oxides. Aquatic fungi have been shown to be responsible for the occurrence of natural Mn oxide (Miyata et al. 2007 and references therein). Unique features of biogenic Mn oxides are their high sorption capacity for metal cations and their ability to oxidize numerous inorganic and organic compounds. Studies on Ascomycetes point to a high similarity between bacterial and fungal $\mathrm{Mn}$ (II) oxidation: both groups use multicopper oxidase-type enzymes as catalysts and layer-type $\mathrm{Mn}(\mathrm{IV})$ oxides as reaction products. The ability to oxidize Mn(II) has been demonstrated for most species of Phoma or Paraconiothyrium
(Coniothyrium) isolated from stream and wetland sediments (Takano et al. 2006). However, further laboratory and field studies are needed to evaluate their potential for remediation of habitats and effluents contaminated with toxic metal(loid) ions. Berg et al. (2007) suggest that Mn concentrations in leaf litter influence litter mass loss rates in the late decomposition stages (up to $5 \mathrm{yr}$ ). This may be due to the fact that manganese peroxidase is produced by a variety of wood-degrading Basidiomycetes and saprophytic fungi in soil. The enzyme oxidizes $\mathrm{Mn}$ (II) to highly reactive $\mathrm{Mn}(\mathrm{III})$ ions, which are stabilized by fungal organic acids until the Mn(III) ions are used to attack the phenolic structures of lignin and humic matter (Steffen et al. 2002).

\section{Humic matter degradation}

Humic substances are among the most abundant and important biopolymers in aquatic ecosystems, and fungal laccases are involved in the transformation of a wide variety of phenolic compounds such as polymeric lignin, humic substances, and xenobiotics (see e.g. Jain et al. 2005, Junghanns et al. 2005, Augustin et al. 2006, Baldrian 2006, Steinberg 2008). Laccases are copper-containing proteins that require $\mathrm{O}_{2}$ to oxidize phenols, polyphenols, aromatic amines, and different non-phenolic substrates by one-electron transfer (Claus 2003). Most ligninolytic fungal species constitutively produce at least one laccase isoenzyme, and laccases dominate ligninolytic enzymes in the soil environment. In freshwater ecosystems, fungi have a high capacity for the decomposition of plant polymers such as lignin, cellulose, and hemicelluloses (Romani et al. 2006). In contrast, activities of key enzymes in the degradation of lignin and cellulose (phenol oxidase and cellobiohydrolase) were undetectable when bacteria were grown alone. Romani et al. (2006) further suggest that fungi provide bacteria with resources that the bacteria were unable to acquire on their own, most likely intermediate decomposition products. Hofrichter \& Fritsche $(1996,1997)$ demonstrated that several wood and litter decaying Basidiomycetes can even depolymerise the high molecular mass fractions of coal humic acids by forming fulvic acid-like compounds using an array of oxidases and peroxidases. Conversely, fungi also form humic substances. These resemble natural aquatic humic matter but contain more aliphatic constituents (carbohydrates, peptides) and fewer aromatic structures (Claus et al. 1999). The ${ }^{13} \mathrm{C}$ and ${ }^{15} \mathrm{~N}$ isotopic contents of the microbially produced humic substances varied with the microbial inoculum and the type of organic substrates used, indicating that anabolic processes are mainly responsi- 
ble for the humification. Interestingly, in deep-sea sediments, fungal hyphae actively form aggregates containing humic substances, carbohydrates, and proteins (Damare \& Raghukumar 2008). Damare \& Raghukumar (2008) even suggest that fungi in these sediments may be involved in humic aggregate formation by processes very similar to those in terrestrial sediments, and point to their relevance for carbon sequestration.

\section{Chitin degradation}

Another important and abundant biopolymer in aquatic ecosystems is chitin (Reisert \& Fuller 1962) in arthropod exoskeletons arthropods and fungal cell walls. The exoskeleton of zooplankton can be densely colonized by aquatic fungi (Czeczuga et al. 2000), particularly when chitinolytic bacteria are suppressed by antibiotics (Tang et al. 2006). Pure chitin was used to isolate 19 species of chitinophilic aquatic fungi (Sparrow 1960), and 95 zoosporic fungus species were found on the fragments of benthic crustaceans in various Polish waters (Czeczuga \& Godlewska 1999). Microbial chitinases catalyze the hydrolysis of chitin, an unbranched polymer of 1,4-N-acetylglucosamine. Thus, chitinases play an important physiological and ecological role in ecosystems by generating carbon and nitrogen sources (Cohen-Kupiec \& Chet 1998). Chitinases and chitosanases are also involved in autolytic, morphogenetic, or nutritional processes, rendering them important for pathogenesis and symbiosis (see e.g. Gooday 1990).

\section{Degradation and detoxification of water pollutants}

The exceptional enzymatic capabilities of aquatic fungi have led to their broad use in biotechnological applications (Adrio \& Demain 2003), including the degradation and detoxification of many organic and inorganic water pollutants. For example, studies on the aquatic hyphomycete Heliscus lugdunensis suggest a role of aquatic fungi in the environmental fate of aquatic pollutants (Augustin et al. 2006). When adding weathered kerosene spiked with naphthalene, pristane, 1,13-tetradecadiene, and n-hexadecane to water-sediment mixtures from 3 lakes in the USA, microbial metabolization of each hydrocarbon was demonstrated. Naphthalene was the most readily metabolized compound, and pristane the most resistant (Cooney et al. 1985). Other studies have demonstrated that many fungi are involved in the degradation of organohalogens (Müller et al. 1996, Romero et al. 2006) and aromatic hydrocarbons including many pesticides as well as azo and anthraquinone dyes (e.g. Mills et al. 1971, Hodkinson 1976, Cerniglia et al. 1992, MacGillivray \& Shiaris 1993, Müncnerová \& Augustin 1994, Cerniglia 1997, El-Hissy et al. 2001, Prenafeta-Boldu et al. 2006, Hesham et al. 2006, Martin et al. 2007, Junghanns et al. 2008). As expected from their vast enzymatic potential, fungi have been found to utilize a huge variety of additional organic pollutants, even including volatile aromatic hydrocarbons as the sole source of carbon and energy (Prenafeta-Boldu et al. 2006 and references therein). However, ubiquitous fungi can also be responsible for chlorination of lignin with implications for global organochlorine production (Ortiz-Bermúdez et al. 2007). Besides organic pollutants, inorganic pollutants such as heavy metals have a pronounced effect on activity and diversity of microbial communities (Duarte et al. 2008) and in a stream sediment fungi have been found to be superior to bacteria in sequestration of cadmium (Massaccesi et al. 2002). A more specific study testing the Cd stress response of the aquatic hyphomycete $H$. lugdunensis at the thiol peptide level revealed that $0.1 \mathrm{mM} \mathrm{Cd}$ increased the glutathione (GSH) content and induced the synthesis of additional thiol peptides (Jaeckel et al. 2005). Further, the simultaneous induction of metallothionein and phytochelatin, which were accompanied by an increase in GSH level, indicates a potential function of these complexing agents for in vivo heavy metal detoxification. These findings imply that fungi can well adapt to heavy metal contaminated waters where they play an important ecological role in organic matter, nutrient, and energy cycling.

\section{METHODOLOGY FOR CHARACTERIZING FUNGI WITHIN THEIR ECOSYSTEM}

Conventional methods for studying fungi in aquatic ecosystem include microscopic and pure-culture approaches, mainly based on fungal propagules or sporangia (e.g. Czeczuga et al. 2005). In recent years, molecular methods such as clone libraries, fingerprint analysis, and phylogenetic trees have increasingly been used in aquatic mycology to include the 'unculturable' and sterile (i.e. non-reproductive) fraction of environmental species. Bärlocher (2007) reviewed molecular methods that have been applied to aquatic hyphomycetes and emphasized their growing importance. For lake ecosystems, a combination of these new methods with conventional approaches is vital, because descriptive work forms the basis for most ecological questions. Here we give a short overview on promising new approaches and how to circumvent associated problems. 


\section{Microscopical examinations}

The in situ examination of fungi in a sample gives valuable information about spatial distribution, biovolume, generation cycles, and abundance of fungi, parameters that are difficult to characterize solely with molecular tools. Therefore, the continued use and development of reliable microscopical methods is essential for environmental microbiologists. Due to the phylogenetic heterogeneity of aquatic fungi (from ancient zoosporic fungi to more recently evolved aquatic hyphomycetes), this is not a trivial undertaking. Classical staining protocols for fungal hyphae with various dyes are listed on the web site of the University of Adelaide (www.mycology.adelaide.edu.au/, also listed in Ellis et al. 2007). The new generation of dyes consists of sensitive fluorophores, which are especially useful for filamentous forms and yeasts. Reliable dyes for fungal cell wall components are Calcofluor White, labelled lectins (Robin et al. 1986, Schüßler et al. 1996), species-specific labelled monoclonal antibodies for cell wall components (Bermingham et al. 1995) and for widely occurring fungal glucans (Marshall et al. 1997, Rachini et al. 2007), or a labelled chitin binding domain (New England Biolabs) for in situ staining of chitin (C. Wurzbacher unpubl. data). Two staining methods were recommended by Kagami et al. (2007) for zoosporic chytrids: Calcofluor White for effective staining of sporangial and rhizoid cell walls and Nile Red combined with DAPI for staining lipids and cell nuclei of fungal zoospores. For identification of active cells (tested mainly for yeasts) FUN-1 (Molecular Probes) (Millard et al. 1997) is commercially available. Hickey et al. (2005) reviewed other fluorescent dyes appropriate for live cell imaging of fungi. Unfortunately, these stains are often not fungus-specific (e.g. Calcofluor White detects $\beta(1,4)$ - and $\beta(1,3)$-glycosidic bonds of $\beta$ D-glucopyranose-polymers such as glucan, cellulose, chitin, murein, pseudomurein), but combined with morphological features fungi can often be easily recognized. Nevertheless, melanized cells and chytrid zoospores remain problematic. Melanized cell walls often remain inaccessible to dyes that target cell wall components such as chitin or glucan (C. Wurzbacher pers. obs.), and the same is true for chytrid zoospores, which lack cell walls and are thus difficult to differentiate from flagellates using Nile Red and DAPI alone.

\section{Applying fluorescence in situ hybridization (FISH) to environmental samples}

Another microscopical approach adressing phylogeny and, to a limited extent, activity, is fluorescence in situ hybridization (FISH) with labeled ribosomal
RNA (rRNA) oligonucleotide probes. This method has become standard in environmental microbiology and is used to quantify taxonomic groups of prokaryotes in situ. In preliminary studies, the method has been applied to fungi on leaves collected from a stream using probes targeting mitochondrial rRNA (McArthur et al. 2001). The hybridization of fungi from cultures and also from environmental leaf samples was successful, but strong autofluorescence of the substrates and other methodological constraints interfered with image analysis. Baschien et al. $(2001,2008)$ came to similar conclusions with probes targeting the fungal ribosomal small and large subunit (SSU and LSU) sequences. Signals could only be detected with a highly sensitive confocal laser scanning microscope. In these studies, different intensities in neighboring cells of a single hyphae were observed (also seen with eukaryotic probes in Gonçalves et al. 2006), which may imply differential metabolic activities of the targeted mycelia or different cell wall permeabilities for the probes. The phenomenon is also consistent with the hypothesis of migratory fungal cytoplasm, which would be highly relevant when measuring fungal activities (for review see Klein \& Paschke 2004).

For Chytrids no suitable probe has been developed yet, but several attempts are in progress (T. SimeNgando pers. comm.). If successful, this would greatly help in measuring abundance and biomass of planktonic fungi. A preliminary solution may be the use of more generalized probes (Table 1), such as PF2 (Kempf et al. 2000, Scupham et al. 2006) or eukaryotic probes such as EUK516 or EUKb-Mix (Amann et al. 1990, Baker et al. 2003).

More work has been invested in yeasts. For ubiquitous Aureobasidium pullulans, a good signal was achieved by multilabelled probes following enzymatic digestion of cell walls (Li et al. 1997, Spear et al. 1999). Kempf et al. (2000) developed probes for the in situ detection of fungal pathogens in blood. More recently, Inacio et al. (2003) generated a map of the variable regions D1 and D2 located in the ribosomal RNA of the LSU for its accessibility for fluorescently labeled probes, which was later extended to other variable regions in the LSU (Röder et al. 2007). A similar map exists for the SSU sequence (Behrens et al. 2003), enabling the development of probes for other fungal taxa (Baker et al. 2004). When designing new probes for fungal groups, these maps may provide a useful starting point, and the software package ARB (http://www.arb-home.de/; see Ludwig et al. 2004) can be used as a suitable probe design tool that also considers secondary structures of rRNA sequences.

In any case, low signal intensities remain problematic. Enzymatic signal amplification, successful for gram-positive bacteria in lakes (Sekar et al. 2003), is 
still not feasible for environmental samples (Spear et al. 1999, Baschien et al. 2008). This is probably due to cell wall penetration problems and low transparency of hyphae and substrate (e.g. melanized cells or lignified substrate). Enzymatic cell wall digestion (targetting chitin or glucan) and chemical postfixation agents can improve the diffusion of molecular probes (Spear et al. 1999, Cimino et al. 2006). Transparency is usually achieved with harsh chemical preparations, which jeopardizes the integrity of labile in situ rRNA. This leaves microtome cuts as a possible solution for highlighting fungal activity in optically dense substrates, such as leaves or macrophytes, although patchy colonization can produce misleading estimates. A detailed description of several FISH methods for prokaryotes and similar problems in soil environments was reviewed by Schmid et al. (2006).

\section{Fingerprint methods and OTUs}

FISH is not the only molecular approach yielding insight into fungal diversity and dynamics. Another method, derived from clinical and environmental microbiology, is the analysis of ribotype diversity of a given community or sample. A polymerase chain reaction (PCR) with appropriate kingdom- or phylumspecific primers of ribosomal genes often reveals sequence patterns that can be analyzed by downstream applications such as denaturing (temperature) gradient gel electrophoresis (D/TGGE), T-RFLP, or automated ribosomal intergenic spacer analysis (ARISA) (Nikolcheva et al. 2003, Nikolcheva \& Bärlocher 2004, Torzilli et al. 2006). These complement cultivation-based methods (Mills et al. 2002, Gadanho \& Sampaio 2004). Fingerprint methods allow comparisons of community patterns in a spatial gradient or in a progressive succession of a distinct habitat and have been used to examine the mycoflora on submerged leaves in rivers (Nikolcheva \& Bärlocher 2005, Raviraja et al. 2005, Das et al. 2007) and to access difficult habitats such as groundwater (Solé et al. 2008). In lake ecosystems, these molecular fingerprints have only been applied in a few cases to fungi: for community profiling during algae and zooplankton degradation (van Hannen et al. 1999, Tang et al. 2006) and for determining the diversity of fungi on macrophytes (Mille-Lindblom et al. 2006a). Fingerprint techniques can also be used to differentiate between isolates (Libkind et al. 2003) or to screen clone libraries (Neubert et al. 2006). Common targets are ribosomal genes, and numerous primers are available for SSU, ITS, and LSU sequences (see Table 1 for the most common primers). Since DGGE patterns typically reveal only the most abundant phylotypes $(\geq 1 \%)$, clone libraries have been used for a more comprehensive assessment of fungal or eukaryotic diversity. Sequential filtration of water samples allows focusing on the most promising size fractions, which, for example, has led to the molecular rediscovery of the planktonic chytrids (Lefranc et al. 2005, Lepère et al. 2006, 2007, 2008, Lefèvre et al. 2007, 2008, Chen et al. 2008). Clone libraries and molecular fingerprints are ideal for gaining an overview on the fungal flora of a distinct, defined habitat (e.g. anoxic sediment) (Takishita et al. 2007) and provide a firm basis for further phylogenetic and functional studies.

\section{Databases, sequences, and primer-coverage}

FISH analysis and PCR-based methods require highly specific oligonucleotide primers with low bias (Anderson et al. 2003). All these molecular tools are highly dependent on the chosen oligonucleotide sequences. Thus, the applicability of oligonucleotides strongly depends on the quality of the dataset used to design them. Many common primer pairs exclude certain fungal taxa (see Table 1) and should be used with caution. In addition to ribosomal genes and their intergenic spacers, which have often been used for fungi, primers target ribosomal and mitochondrial genes, or the $\beta$-tubulin gene. A large set of fungal primers can be found on the web sites of Lutzoni's (www.lutzonilab.net/) and Bruns (http://plantbio. berkeley.edu/ bruns/) laboratories. Mitchell \& Zuccaro (2006) summarized primers used in environmental studies. The ribosomal genomic DNA region of fungi contains highly variable locations suitable for phylogenetic analysis and fingerprint methods. Whereas the SSU (17-18S) and 5.8S sequence are rather conservative, the ITS, IGS, and LSU (24S-26S) regions can be highly variable in base composition and sequence length. For filamentous fungi the SSU and the ITS regions are commonly used for fingerprint methods and phylogenetic analysis, whereas for yeasts most studies have relied on variable LSU regions, which allow differentiation among almost all described species (Fell et al. 2000). A major problem of these approaches continues to be the scarcity of representative sequences in public databases. The SILVA rRNA database project (Pruesse et al. 2007) provides the first quality-checked database for eukaryotes that can be used as a basis for phylogenetic trees or to develop adequate primers and probes. The eukaryotic dataset for fungi is far from complete: from 65403 fungal entries in the primary database of LSU sequences, only 1068 quality checked sequences are provided in the tree; and for SSU sequences 8356 revised sequences from 35190 primary entries are present in the tree. ITS 
Table 1. Primer and probe coverage determined using ARB software and the small subunit (SSU)/large subunit (LSU) database (SILVA) allowing 0 mismatches. ${ }^{*}$ Database sequences that terminate with primer sequence, no total data can be determined; checked on excluded taxa only; ${ }^{* *}$ wrongly classified in literature (Kempf et al. 2000); nd: not determined

\begin{tabular}{|c|c|c|c|}
\hline & Target region & Kingdom coverage $(\%)$ & Excluded taxa \\
\hline \multicolumn{4}{|l|}{ Primer } \\
\hline NS1 & SSU & Representatives of all taxa* & nd \\
\hline Fung & SSU & 58 & Zygomycota, Chytridiomycota \\
\hline ITS1 & SSU & Representatives of all taxa ${ }^{*}$ & Sordariomycetes, few yeast and Penicillium spp. \\
\hline ITS3 & $5.8 \mathrm{~S}$ & nd & nd \\
\hline ITS4/NL1 & LSU & Representatives of all taxa* & $\begin{array}{l}\text { Blastocladiomycota, few genera (Rozella, Neurospora, } \\
\text { Schizosaccharomycetes) }\end{array}$ \\
\hline LS2 & LSU & 73 & $\begin{array}{l}\text { Sordariomycetes, Chytridiomycota, Zygomycota, few yeasts, } \\
\text { few genera }\end{array}$ \\
\hline NL4/D2R & LSU & 85 & Several Saccharomycetales, few genera \\
\hline \multicolumn{4}{|l|}{ Probe } \\
\hline EUK516 & SSU & 96 & Few genera \\
\hline EUKb1193 & SSU & 93 & Few genera \\
\hline EUKb503 & SSU & 96 & Few genera \\
\hline EUKb310 & SSU & 92 & Few Glomeromycota and yeasts \\
\hline MY1574 & SSU & 85 & Several Zygomycota, Chytridiomycota and yeasts \\
\hline PF2 & $\mathrm{LSU}^{* *}$ & 70 & Several groups of all taxa, including yeasts \\
\hline
\end{tabular}

data are entirely absent in the database. Nevertheless, all 3 regions have been used for clone libraries and community fingerprints (e.g. SSU: Lefèvre et al. 2007, Nikolcheva et al. 2003, ITS: Raviraja et al. 2005, Nikolcheva et al. 2005, Neubert et al. 2006 and LSU: Schadt et al. 2003, Gadanho \& Sampaio 2004). The SSU region has only limited phylogenetic resolution below the genus level. In contrast, the ITS has high resolution and is often used for species identification, but is problematic for building realistic phylogenetic trees because of its length polymorphism and vulnerability to inversions and deletions. The LSU is more stable than ITS with a similar phylogenetic resolution in its divergent domains (e.g. D1, D2, D7, D8) (Röder et al. 2007) and is often suitable for species identification (see e.g. Sampaio et al. 2007). In difficult cases, both regions have been used for identification of isolates (Butinar et al. 2007).

\section{Quantifying fungal biomass}

Quantifying fungal biomass and growth is of great importance for microbial ecologists, and the main approaches have been reviewed elsewhere (Newell 1993, Gessner \& Newell 2002, Gessner et al. 2003, Klein \& Paschke 2004, Gessner et al. 2007, Suberkropp 2008). The major emphasis has been on comparing biomasses and productivities of fungi and bacteria. For fungi, ergosterol is used as indicator molecule and has largely replaced direct measurements of cell biovolumes with the microscope. Ergosterol is part of the fungal membrane, occurs in a relatively constant ratio to total biomass, and is largely restricted to living cells of higher fungi (Ascomycota and Basidiomycota) (Gessner et al. 2003). However, it may persist after fungal death when protected from light (Mille-Lindblom et al. 2004). Many Zygomycetes and all Chytridomycetes (as well as Oomycetes) do not contain ergosterol and are therefore not measured-a potential gap in our knowledge of aquatic fungi sensu lato. To fill this gap, Chytrid biomass could be estimated by FISH, combined with microscopic measurements of cell size. Fluorescent dyes can contribute to total biomass estimates detecting cell wall components such as chitin, glucan (Rasconi et al. 2009), or protein activity (Klein \& Paschke 2004 and references therein). Highly sensitive molecular tools are suitable for quantifying fungal, bacterial, and archeal genes of environmental samples (Manerkar et al. 2008), although optimization is still needed. Conversely, our estimates of 'bacterial' productivity do not differentiate between Bacteria and Archaea, and Archaea appear to be present wherever we look for them, e.g. on leaves decaying in streams (Manerkar et al. 2008) or submerged in lakes (Chan et al. unpubl.). Bacterial and archaeal biomass is measured after litter has been treated with sodiumpyrophosphate and ultrasound to detach the cells (Büsing $\&$ Gessner 2002). This procedure might be error-prone because it lyses sensitive fractions of prokaryotic cells and neglects filaments and cells growing within the substrate. However, the simultaneous quantification of the 3 microbial groups seems an important step toward a better understanding of degradation processes coupled with microbial colonization in general. A promising method, which can be coupled with the use of sta- 
ble isotopes for production measurements, is PFLA analysis (Hedrick et al. 2007). It has been used for sediments and terrestrial ecosystems. Although the interpretation is still critical, simultaneous measurements of living microbial cells of different groups is possible. However, PFLA analysis remains to be evaluated for aquatic fungi.

\section{Further methods of great potential}

Quantitative real-time PCR has the potential to measure marker genes down to a few hundred copies. Ideally, it should run with a single-copy gene (therefore, ribosomal genes are not recommended) and a fragment length of under $250 \mathrm{bp}$ (Perez-Osorio \& Franklin 2008). Different microbial groups could be measured, in combination with multiplex PCR, simultaneously. In addition to ergosterol measured via HPLC, other biomolecules could help to estimate total fungal biomass: Glucan is the major cell wall constituent of fungi, and a commercialized test system (Glucatell) exists but has yet to be tested with environmental samples. Chitin also occurs in all true fungi (Eumycota), though at varying levels, but is considered unsuitable due to a lack of sufficiently sensitive methods (Gessner et al. 2003). When chitin is hydrolyzed to its monomers, it is possible to calculate fungal and bacterial biomass simultaneously via HPLC (Appuhn 2004, Klein \& Paschke 2004 and references therein). The suitability of this method for aquatic mycology, however, remains to be evaluated. Despite the high potential of molecular biology for aquatic mycology, all the information we obtained from samples via sequencing lacks context without species identifications coupled to a reliable, comprehensive database. So far only a tiny proportion of validly described aquatic fungi is represented in molecular databases. For example, from the 1300 known Chytrid species only 73 sequences of classified species are present in the SILVA SSU database. This is an enormous drawback when trying to interpret sequence data obtained during a field study, and matching them with, for example, species descriptions from Sparrow's monograph (1960). 'New' phylogenetic clades such as LKM11, based exclusively on environmental sequences, might include known species. For combining conventional techniques with molecular tools in addition to FISH, laser microdissection microscopy (LMDM) seems ideal. This procedure would allow coupling morphological species identification or description with molecular identification. Similar to the LMDM, the use of micromanipulators permits studying interspecies relationships independent of experimental setups and may help connecting species to their natural substrate preferences. Conventional studies, based on microscopical examination and identification (Czeczuga et al. 2005, van Ryckegem et al. 2007) can be used to update sequence databases and to complete original descriptions with molecular definitions.

Of course, we cannot ignore new molecular tools such as metagenomics and transcriptomics for future research: they can give us a glimpse into the overall genetic diversity that is present and or active (Bhadauria et al. 2007). If the emphasis is narrowed to a defined experimental system with known isolates, this may help to identify key processes of geochemical cycles. More insight into diversity can also be gained if the information is reduced to ribosomal genes or rRNA by ribotag sequencing, as has been done for soil microbes (Urich et al. 2008). On the other hand, meta-sequence data require intensive bioinformatic postexperimental work and additional personnel, which greatly reduces its practicality. A cost-saving alternative could be the use of chips, based on microarray technology for phylogenetic groups or for functional genes (He et al. 2007, Shimoyama et al. 2009). Once available, this could rapidly characterize the mycoflora of a habitat of interest. In the foreseeable future, however, many fundamental questions in aquatic mycology in lakes remain that can be approached with a combination of traditional and well-established molecular methods.

\section{CONCLUDING REMARKS}

Fungal habitats in lake ecosystems are numerous, diverse, and often hidden. Not only fungal diversity but also important energy transformation processes related to fungal activities need to be scientifically assessed. Although emergent macrophytes have been well studied in respect to fungi, many potential fungal habitats and mechanisms remain understudied. These include submerged and floating macrophytes, nutrient circulation in the pelagic zone, and fungal activities and occurrence in anoxic and oxic lake sediments. Fungi in lake ecosystems can be divided into 2 major morphological forms: (1) filamentous fungi dominating the littoral zone and (2) unicellular fungi dominating the pelagic zone (Fig. 3). The limnetic energy transfer is mainly mediated by particles: CPOM and FPOM. CPOM provides an ideal organic matter matrix for filamentous fungi to grow and scavenge nutrients after hyphal penetration of the particles. Thus, in addition to physical processes, filamentous fungi accelerate CPOM remineralisation leading to the formation of FPOM. These particles are usually too small to sustain growth of filamentous fungi and can rapidly transfer into the pelagic zone. However, FPOM provides a 


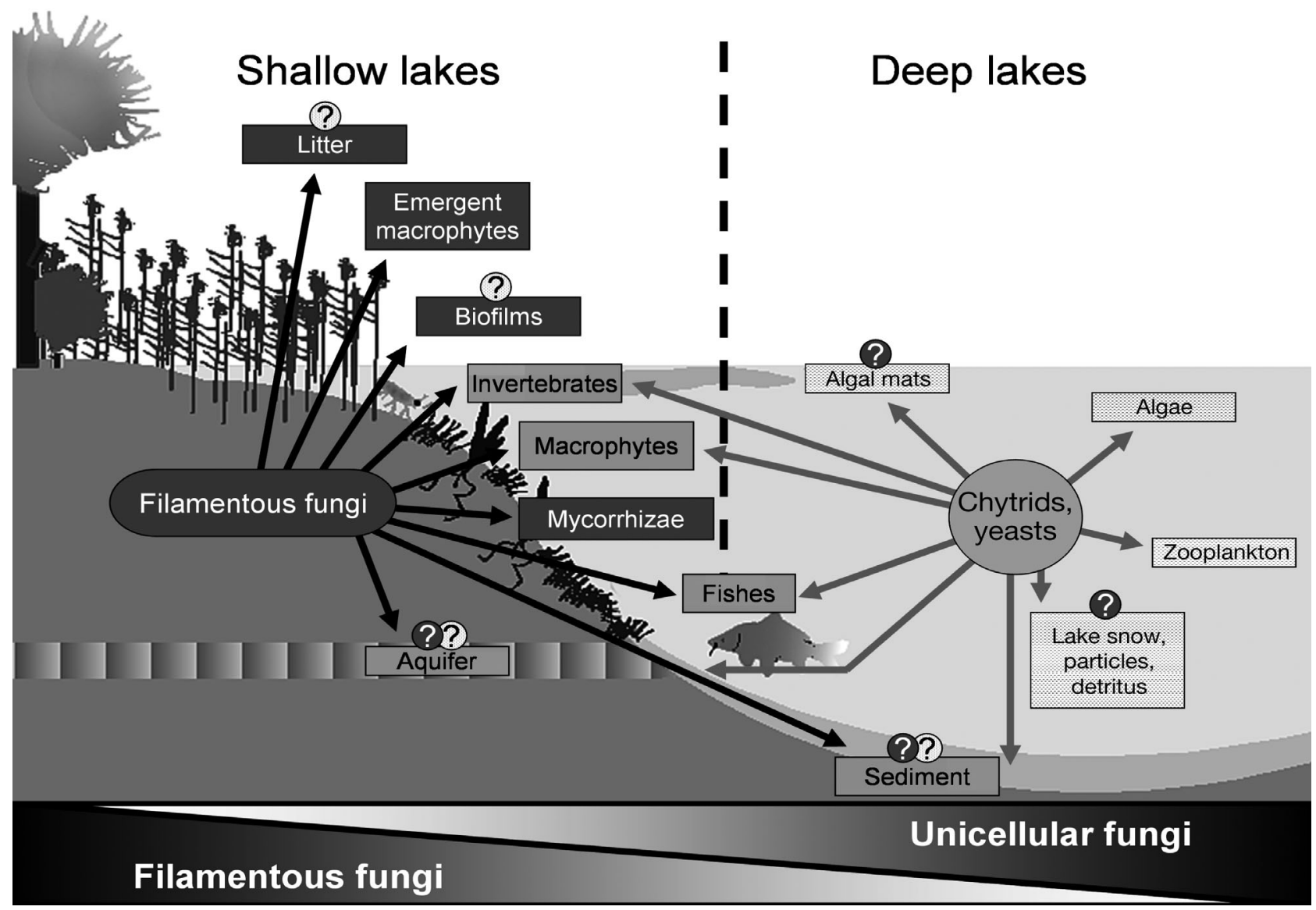

Fig. 4. Fungal flora in shallow and deep lakes and their diverse interactions with important lake elements; question marks indicate need for further research

good substrate for unicellular fungi, which are well adapted to penetrate small particles with short rhizoids. Therefore, the abundance of both fungal morphotypes depends greatly on the quantity of CPOM and FPOM (Fig. 3). This 'morphotype concept' can also be applied to shallow and deep lakes (Fig. 4). The fungal flora will thereby be dominated by either one or the other morphotype, mainly depending on the number and structure of microhabitats with different effects on food web dynamic as well as nutrient and energy cycling. For example, shallow lakes are dominated by a dense coverage of macrophytes that aerate the sediment via their aerenchyma and can serve as mycorrhizal hosts for filamentous fungi (see Table S1 in the supplement, Fig. 4). Most of the interactions depicted in Fig. 4 have been discussed in the present study (see also Table S1 in the supplement). However, many important questions related to occurrence, diversity, and ecological role of fungi in lakes remain unanswered, and we strongly encourage further research in aquatic mycology. In particular, a clever combination of microscopical, molecular, and analytical techniques seems to provide a powerful tool to simultaneously unravel diversity and the ecological role of fungi in aquatic systems. According to the famous yeast specialist H. J. Phaff: 'Ecology is the most exciting aspect of yeast biology'. In his interpretation, ecology focuses on 'how yeasts interact with other organisms, but more importantly, where they live, and why they live there' (Lachance 2003, p. 166). Today, many tools and methodological approaches are available to study the fascinating diversity of fungal lifestyles and their ecological roles in lake ecosystems.

Acknowledgements. The authors thank I. Salka and K. Pohlmann for the revision of earlier versions of this manuscript, and P. S. Kunz for his help in designing the graphs.

\section{LITERATURE CITED}

Abdullah SK, Taj-Aldeen SJ (1989) Extracellular enzymatic activity of aquatic and aero-aquatic conidial fungi. Hydrobiologia 174:217-223

Adrio JL, Demain AL (2003) Fungal biotechnology. Int Microbiol 6:191-199

Ahearn DG, Roth FJ, Meyers SP (1968) Ecology and characterization of yeasts from aquatic regions of South Florida. Mar Biol 1:291-308 
Ali EH, Abdel-Raheem A (2003) Distribution of zoosporic fungi in the mud of major Egyptian lakes. J Basic Microbiol 43:175-184

Alster A, Zohary T (2007) Interactions between the bloomforming dinoflagellate Peridinium gatunense and the chytrid fungus Phlyctochytrium. Hydrobiologia 578:131-139

> Amann RI, Binder BJ, Olson RJ, Chisholm SW, Devereux R, Stahl DA (1990) Combination of 16S rRNA-targeted oligonucleotide probes with flow cytometry for analyzing mixed microbial populations. Appl Environ Microbiol 56: $1919-1925$

Anderson I, Campbell C, Prosser J (2003) Potential bias of fungal $18 \mathrm{~S}$ rDNA and internal transcribed spacer polymerase chain reaction primers for estimating fungal biodiversity in soil. Environ Microbiol 5:36-47

Apinis AE, Chesters CG, Talogoola KH (1972a) Colonization of Phragmites communis Trin leaves by fungi. Nova Hedwigia 23:113-124

Apinis AE, Chesters CG, Talogoola KH (1972b) Microfungi colonizing submerged standing culms of Phragmites communis Trin. Nova Hedwigia 23:473-480

Appuhn A (2004) Die mikrobielle Besiedlung von Wurzeloberfläche und Rhizosphäre in ihrer Bedeutung für Stoffumsätze in Böden. PhD thesis, Universität Kassel

Artz R, Anderson I, Chapman S, Hagn A, Schloter M, Potts J, Campbell C (2007) Changes in fungal community composition in response to vegetational succession during the natural regeneration of cutover peatlands. Microb Ecol 54:508-522

Augustin T (2003) Untersuchungen zum Organika-Abbaupotential aquatischer Hyphomyceten. PhD thesis, Mathematisch-Naturwissenschaftlich-Technischen Fakultät der Martin-Luther-Universität Halle-Wittenberg

Augustin T, Schlosser D, Baumbach R, Schmidt J, Grancharov K, Krauss G, Krauss GJ (2006) Biotransformation of 1-Naphthol by a strictly aquatic fungus. Curr Microbiol 52:216-220

Aumen NG (1980) Microbial succession on a chitinous substrate in a woodland stream. Microb Ecol 6:317-327

Babenzien HD, Babenzien C (1985) Microbial activities at Lake Stechlin. In: Casper SJ (ed) Lake Stechlin, a temperate oligotrophic lake. Dr. W. Junk Publishers, Dordrecht

Baker BJ, Hugenholtz P, Dawson SC, Banfield JF (2003) Extremely acidophilic protists from acid mine drainage host rickettsiales-lineage endosymbionts that have intervening sequences in their 16S rRNA genes. Appl Environ Microbiol 69:5512-5518

Baker BJ, Lutz MA, Dawson SC, Bond PL, Banfield JF (2004) Metabolically active eukaryotic communities in extremely acidic mine drainage. Appl Environ Microbiol 70: 6264-6271

Baldrian P (2006) Fungal laccases - occurrence and properties. FEMS Microbiol Rev 30:215-242

Baldy V, Chauvet E, Charcosset JY, Gessner MO (2002) Microbial dynamics associated with leaves decomposing in the mainstem and floodplain pond of a large river. Aquat Microb Ecol 28:25-36

Bärlocher F (1997) Pitfalls of traditional techniques when studying decomposition of vascular plant remains in aquatic habitats. Limnetica 13:1-11

Bärlocher F (2007) Molecular approaches applied to aquatic hyphomycetes. Fungal Biol Rev 21:19-24

Bärlocher F, Biddiscombe NR (1996) Geratology and decomposition of Typha latifolia and Lythrum salicaria in a freshwater marsh. Arch Hydrobiol 136:309-325

Bärlocher F, Kendrick B (1974) Dynamics of the fungal population on leaves in a stream. J Ecol 62:761-791
Bärlocher F, Porter C (1986) Digestive enzymes and feeding strategies of three stream invertebrates. J N Am Benthol Soc 5:58-66

Bärlocher F, Seena S, Wilson KP, Williams DD (2008) Raised water temperature lowers diversity of hyporheic aquatic hyphomycetes. Freshw Biol 53:368-379

Barron G (1992) Lignolytic and cellulolytic fungi as predators and parasites. In: Carroll G, Wicklow D (eds) The fungal community: its organization and role in the ecosystem, Vol 9, 2nd edn. Marcel Dekker, New York, p 311-326

> Baschien C, Manz W, Neu TR, Szewzyk U (2001) I. Decomposition and microbial activities fluorescence in situ hybridization of freshwater fungi. Int Rev Hydrobiol 86: 371-381

> Baschien C, Manz W, Neu TR, Marvanova L, Szewzyk U (2008) In situ detection of freshwater fungi in an alpine stream by new taxon-specific fluorescence in situ hybridization probes. Appl Environ Microbiol 74:6427-6436

Beck-Nielsen D, Vindbaek Madsen T (2001) Occurrence of vesicular-arbuscular mycorrhiza in aquatic macrophytes from lakes and streams. Aquat Bot 71:141-148

Behrens S, Ruhland C, Inacio J, Huber H and others (2003) In situ accessibility of small-subunit rRNA of members of the domains Bacteria, Archaea, and Eucarya to Cy3-labeled oligonucleotide probes. Appl Environ Microbiol 69: 1748-1758

Bengtsson G (1992) Interactions between fungi, bacteria and beech leaves in a stream microcosm. Oecologia 89: 542-549

> Benner R, Newell SY, Maccubbin AE, Hodson RE (1984) Relative contributions of bacteria and fungi to rates of degradation of lignocellulosic detritus in salt-marsh sediments. Appl Environ Microbiol 48:36-40

Benner R, Moran M, Hodson R (1986) Biogeochemical cycling of lignocellulosic carbon in marine and freshwater ecosystems: relative contributions of procaryotes and eucaryotes. Limnol Oceanogr 31:89-100

> Berg B, Steffen K, McClaugherty C (2007) Litter decomposition rate is dependent on litter Mn concentrations. Biogeochemistry 82:29-39

Bermingham S, Dewey F, Maltby L (1995) Development of a monoclonal antibody-based immunoassay for the detection and quantification of Anguillospora longissima colonizing leaf material. Appl Environ Microbiol 61: 2606-2613

> Bhadauria V, Popescu L, Zhao W, Peng Y (2007) Fungal transcriptomics. Microbiol Res 162:285-298

Bohman I (2005) Coarse detritus in oligotrophic lake littoral zones - utilization by invertebrates and contribution to carbon flow. PhD thesis, University of Kalmar

Brad T, Braster M, van Breukelen BM, van Straalen NM, Roling WFM (2008) Eukaryotic diversity in an anaerobic aquifer polluted with landfill leachate. Appl Environ Microbiol 74:3959-3968

Braun A (1856) Über Chytridium, eine Gattung einzelliger Schmarotzergewächse auf Algen und Infusorien. Abhandl Berlin Akad 1855:21-83

> Brinson MM, Lugo AE, Brown S (1981) Primary productivity, decomposition and consumer activity in freshwater wetlands. Annu Rev Ecol Syst 12:123-161

Buchan A, Newell S, Moreta J, Moran M (2002) Analysis of internal transcribed spacer (ITS) regions of rRNA genes in fungal communities in a southeastern U.S. salt marsh. Microb Ecol 43:329-340

> Buchan A, Newell SY, Butler M, Biers EJ, Hollibaugh JT, Moran MA (2003) Dynamics of bacterial and fungal communities on decaying salt marsh grass. Appl Environ Microbiol 69:6676-6687 
Buesing N, Gessner MO (2002) Comparison of detachment procedures for direct counts of bacteria associated with sediment particles, plant litter and epiphytic biofilms. Aquat Microb Ecol 27:29-36

Butinar L, Santos S, Spencer-Martins I, Oren A, GundeCimerman N (2005) Yeast diversity in hypersaline habitats. FEMS Microbiol Lett 244:229-234

Butinar L, Spencer-Martins I, Gunde-Cimerman N (2007) Yeasts in high arctic glaciers: the discovery of a new habitat for eukaryotic microorganisms. Antonie van Leeuwenhoek 91:277-289

Cai L, Tsui C, Zhang K, Hyde K (2002) Aquatic fungi from Lake Fuxian, Yunnan, China. Fungal Divers 9:57-70

> Canter H, Heany S (1984) Observations on zoosporic fungi of Ceratium spp. in lakes of the English Lake District; importance for phytoplankton population dynamics. New Phytol 97:601-612

Canter-Lund H, Lund J (1995) Freshwater algae-their microscopic world explored. Biopress, Bristol

> Cantrell S, Casillas-Martínez L, Molina M (2006) Characterization of fungi from hypersaline environments of solar salterns using morphological and molecular techniques. Mycol Res 110:962-970

Casper SJ (1965) Hyphomyceten-Studien. I. Die SüßwasserHyphomyceten des Stechlinsee-Gebietes. Limnologica 3: $257-270$

Casper SJ, Krey L, Proft G (1985) Fallen leaves in Lake Stechlin. In: Casper SJ (ed) Lake Stechlin: a temperate oligotrophic lake. Dr. W. Junk Publishers, Dordrecht

> Cerniglia CE (1997) Fungal metabolism of polycyclic aromatic hydrocarbons: past, present and future applications in bioremediation. J Ind Microbiol Biotechnol 19:324-333

Cerniglia C, Sutherland J, Crow S (1992) Fungal metabolism of aromatic hydrocarbons. In: Winkelmann G (ed) Microbial degradation of natural products. Wiley-VCH, Weinheim

> Chen M, Chen F, Yu Y, Ji J, Kong F (2008) Genetic diversity of eukaryotic microorganisms in Lake Taihu, a large shallow subtropical lake in China. Microb Ecol 56:572-583

Chergui H, Pattee E (1990) The processing of leaves of trees and aquatic macrophytes in the network of the River Rhone. Int Rev Gesamten Hydrobiol Hydrograph 75: 281-302

Cimino M, Alamo L, Salazar L (2006) Permeabilization of the mycobacterial envelope for protein cytolocalization studies by immunofluorescence microscopy. BMC Microbiol 6:35

> Claus H (2003) Laccases and their occurrence in prokaryotes. Arch Microbiol 179:145-150

> Claus H, Filip Z (1998) Degradation and transformation of aquatic humic substances by laccase-producing fungi Cladosporium cladosporioides and Polyporus versicolor. Acta Hydrochim Hydrobiol 26:180-185

> Claus H, Gleixner G, Filip Z (1999) Formation of humic-like substances in mixed and pure cultures of aquatic microorganisms. Acta Hydrochim Hydrobiol 27:200-207

> Cohen-Kupiec R, Chet I (1998) The molecular biology of chitin digestion. Curr Opin Biotechnol 9:270-277

Collins VG, Willoughby LG (1962) The distribution of bacteria and fungal spores in Blelham Tarn with particular reference to an experimental overturn. Arch Microbiol 43: 294-307

Cooke W (1976) Fungi in sewage. In: Jones E (ed) Recent advances in aquatic mycology. Elek Science, London, p 389-434

Cooke W, Matsuura G (1963) A study of yeast populations in a waste stabilization pond system. Protoplasma 57:163-187
Cooney JJ, Silver SA, Beck EA (1985) Factors influencing hydrocarbon degradation in three freshwater lakes. Microb Ecol 11:127-137

> Cross T (1981) Aquatic actinomycetes: a critical survey of the occurrence, growth and role of actinomycetes in aquatic habitats. J Appl Microbiol 50:397-423

> Czeczuga B (1991) Studies of aquatic fungi. XVIII. aquatic fungi in Lake Sniardwy and eighteen neighbouring lakes. Int Rev Gesamten Hydrobiol Hydrograph 76:121-135

Czeczuga B, Godlewska A (1999) Zoosporic fungus species growing on dead benthos crustaceans. Pol J Environ Stud 8:377-382

Czeczuga B, Godlewska A, Kozlowska M (2000) Zoosporic fungi growing on the carapaces of dead zooplankton organisms. Limnologica 30:37-43

Czeczuga B, Kozlowska M, Godlewska A (2002) Zoosporic aquatic fungi growing on dead specimens of 29 freshwater crustacean species. Limnologica 32:180-193

Czeczuga B, Mazalska B, Godlewska A, Muszynska E (2005) Aquatic fungi growing on dead fragments of submerged plants. Limnologica 35:283-297

da Silva M, Umbuzeiro G, Pfenning L, Canhos V, Esposito E (2003a) Filamentous fungi isolated from estuarine sediments contaminated with industrial discharges. Soil Sediment Contam 12:345-356

da Silva M, Cerniglia C, Pothuluri J, Canhos V, Esposito E (2003b) Screening filamentous fungi isolated from estuarine sediments for the ability to oxidize polycyclic aromatic hydrocarbons. World J Microb Biot 19:399-405

- Dadachova E, Bryan RA, Huang X, Moadel T and others (2007) Ionizing radiation changes the electronic properties of melanin and enhances the growth of melanized fungi. PLoS ONE 2:e457, doi:10.1371/journal.pone.0000457

Damare S, Raghukumar C (2008) Fungi and macroaggregation in deep-sea sediments. Microb Ecol 56:168-177

> Das M, Royer T, Leff L (2007) Diversity of fungi, bacteria, and actinomycetes on leaves decomposing in a stream. Appl Environ Microbiol 73:756-767

- Davis C, van der Valk A (1978) The decomposition of standing and fallen litter of Typha glauca and Scirpus fluviatilis. Can J Bot 56:662-675

Dawson SC, Pace NR (2002) Novel kingdom-level eukaryotic diversity in anoxic environments. Proc Natl Acad Sci USA 99:8324-8329

de Bruin A, Ibelings B, Kagami M, Mooij WM, van Donk E (2008) Adaptation of the fungal parasite Zygorhizidium planktonicum during 200 generations of growth on homogeneous and heterogeneous populations of its host, the diatom Asterionella formosa. J Eukaryot Microbiol 55: 69-74

Duarte S, Pascoal C, Cássio F (2008) High diversity of fungi may mitigate the impact of pollution on plant litter decomposition in streams. Microb Ecol 56:688-695

Durán A, Nombela C (2004) Fungal cell wall biogenesis: building a dynamic interface with the environment. Microbiology 150:3099-3103

Ebert D (2005) Ecology, epidemiology and evolution of parasitism in daphnia. National Library of Medicine, National Center for Biotechnology Information, Bethesda, MD. Accessed 1 June 2009. http://www.ncbi.nlm.nih.gov/ bookshelf/br.fcgi? book=daph

- Ekendahl S, O'Neill A, Thomsson E, Pedersen K (2003) Characterisation of yeasts isolated from deep igneous rock aquifers of the Fennoscandian Shield. Microb Ecol 46: $416-428$

El-Hissy F, Khallil A, El-Nagdy M (1990) Fungi associated with some aquatic plants collected from freshwater areas 
at Assiut (upper Egypt). J Islam Acad Science 3:298-304

El-Hissy F, Nassar M, Khallil A, Abdel-Motaal F (2001) Aquatic fungi recovered from water and submerged mud polluted with industrial effluents. Online J Biol Sci 1: $854-858$

Ellis D, Davis S, Alexiou H, Handke R, Bartley R (2007) Descriptions of medical fungi, 2nd edn. University of Adelaide, Adelaide. Also available at: www.mycology. adelaide.edu.au/downloads/Mycology-BookWEB.pdf

Ellis MB, Ellis JP (1985) Microfungi on land plants: an identification handbook, 1st edn. Macmillan, New York

Falconer G, Wright J, Beall H (1933) The decomposition of certain types of fresh litter under field conditions. Am J Bot 20:196-203

Farmer A (1985) The occurrence of versicular-arbuscular mycorrhiza in isoetid-type submerged aquatic macrophytes under naturally varying conditions. Aquat Bot 21:245-249

Fell J, Boekhout T, Fonseca A, Scorzetti G, Statzell-Tallman A (2000) Biodiversity and systematics of basidiomycetous yeasts as determined by large-subunit rDNA D1/D2 domain sequence analysis. Int $\mathrm{J}$ Syst Evol Microbiol 50:1351-1371

Fischer H, Mille-Lindblom C, Zwirnmann E, Tranvik LJ (2006) Contribution of fungi and bacteria to the formation of dissolved organic carbon from decaying common reed (Phragmites australis). Arch Hydrobiol 166:79-97

Flegler S, McNabb C, Fields W (1974) Antibiotic treatment of lake sediments to determine effect of fungi on decomposition. Water Res 8:307-310

Gadanho M, Sampaio J (2004) Application of temperature gradient gel electrophoresis to the study of yeast diversity in the estuary of the Tagus River, Portugal. FEM Yeast Res 5:253-261

Gadd G (ed) (2006) Fungi in biogeochemical cycles. Cambridge University Press, Cambridge

> Gadd G (2007) Geomycology: biogeochemical transformations of rocks, minerals, metals and radionuclides by fungi, bioweathering and bioremediation. Mycol Res 111: $3-49$

> Gall J, Duringer P, Krumbein W, Paicheler J (1994) Impact of microbial ecosystems on sedimentation. Palaeogeogr Palaeocl Palaeoecol 111:17-28

Gasith A, Hasler AD (1976) Airborne litterfall as a source of organic matter in lakes. Limnol Oceanogr 21:253-258

Gavrishova NA (1981) Distribution of actinomycetes in natural waters (a survey). Hydrobiol J 17:24-31

Gessner M, Newell S (2002) Biomass, growth rate, and production of filamentous fungi in plant litter. In: Hurst $C$, Crawford R, Knudsen G, McInerney M, Stetzenbach L (eds) Manual of environmental microbiology, Vol 2, 2nd edn. American Society for Microbiology Press, Washington, DC, p 390-408

Gessner MO, Van Ryckegem G (2003) Water fungi as decomposers in freshwater ecosystems. In: Bitton G (ed) Encyclopaedia of environmental microbiology. Wiley, New York, p 1-38

Gessner M, Schieferstein B, Müller U, Barkmann S, Lenfers U (1996) A partial budget of primary organic carbon flows in the littoral zone of a hardwater lake. Aquat Bot 55:93-105

Gessner MO, Suberkropp K, Chauvet E (1997) Decomposition of plant litter by fungi in marine and freshwater ecosystems. In: Wicklow GC, Söderström B (eds) The mycota, Vol 4. Springer, Berlin, p 303-322

Gessner M, Bärlocher F, Chauvet E (2003) Qualitative and quantitative analyses of aquatic hyphomycetes in streams. In: Tsui C, Hyde K (eds) Freshwater mycology: fungal diversity research, Vol 10. Fungal Diversity Press, Hong Kong, p 127-157

Gessner M, Gulis V, Kuehn K, Chauvet E, Suberkropp K (2007) Fungal decomposers of plant litter in aquatic ecosystems. In: Kubicek C, Druzhinia I (eds) Environmental and microbial relationships: the Mycota, Vol 4. Springer, Berlin, p 301-324

Gilbert O, Giavarini V (2000) The lichen vegetation of lake margins in Britain. Lichenologist 32:365-386

Gimmler H (2001) Mutalistic relationships between algae and fungi (excluding lichens). In: Esser K, Lüttge U, Kadereit JW, Beyschlag W (eds) Progress in botany, Vol 62. Springer, Berlin, p 194-214

> Giraud F, Guiraud P, Kadri M, Blake G, Steiman R (2001) Biodegradation of anthracene and fluoranthene by fungi isolated from an experimental constructed wetland for wastewater treatment. Water Res 35:4126-4136

Gleason F (1976) The physiology of the lower freshwater fungi. In: Jones E (ed) Recent advances in aquatic mycology. Elek Science, London, p 543-572

- Gleason FH, Kagami M, Lefèvre E, Sime-Ngando T (2008) The ecology of chytrids in aquatic ecosystems: roles in food web dynamics. Fungal Biol Rev 22:17-25

Godshalk G, Wetzel R (1978) Decomposition of aquatic angiosperms. II. Particulate components. Aquat Bot 5: 301-327

> Goedkoop W, Widenfalk A, Haglund AL, Steger K, Bertilsson S (2005) Microbial characterization of artificial sediment and comparisons with natural sediments-implications for toxicity testing. Environ Toxicol Chem 24:2725-2733

Goh T, Hyde K (1996) Biodiversity of freshwater fungi. J Ind Microbiol Biotechnol 17:328-345

Gonçalves A, Santos I, Paterson R, Lima N (2006) FISH and Calcofluor staining techniques to detect in situ filamentous fungal biofilms in water. Rev Iberoam Micol 23: 194-198

Gooday GW (1990) Physiology of microbial degradation of chitin and chitosan. Biodegradation 1:177-190

> Gross S, Robbins EI (2000) Acidophilic and acid-tolerant fungi and yeasts. Hydrobiologia 433:91-109

Gulis V, Kuehn KA, Suberkropp K (2009) Fungi. In: Likens EG (ed) Encyclopedia of inland waters. Academic Press, Oxford, p 233-243

Gunde-Cimerman N, Zalar P, de Hoog S, Plemenitas A (2000) Hypersaline waters in salterns - natural ecological niches for halophilic black yeasts. FEMS Microbiol Ecol 32: $235-240$

Hagler A (2006) Yeasts as indicators of environmental quality. In: Gábor P, Carlos R (eds) Biodiversity and ecophysiology of yeasts. Springer, Berlin, p 515-532

Hanlon R (1981) Allochthonous plant litter as a source of organic material in an oligotrophic lake (Llyn Frongoch). Hydrobiologia 80:257-261

Hao Y, Mo M, Su H, Zhang K (2005) Ecology of aquatic nematode-trapping hyphomycetes in southwestern China. Aquat Microb Ecol 40:175-181

> He Z, Gentry TJ, Schadt CW, Wu L and others (2007) GeoChip: a comprehensive microarray for investigating biogeochemical, ecological and environmental processes. ISME J 1:67-77

> Heckman DS, Geiser DM, Eidell BR, Stauffer RL, Kardos NL, Hedges SB (2001) Molecular evidence for the early colonization of land by fungi and plants. Science 293: $1129-1133$

Hedrick L, Soyugenc M (1967) Yeasts and molds in water and sediments of Lake Ontario. In: Elder FC, Langford GB, Chandler DC (eds) Proc 10th Conf Great Lakes Res, April 
1967, Toronto. International Association for Great Lakes Research, Ann Arbor, MI, p 10-30

Hedrick L, Soyugenc M, DuPont P, Ambrosini R (1964) Yeasts in Lake Michigan and Lake Erie. In: Everett NM (ed) Proc 7th Conf Great Lakes Res, April 1964, Toronto. University of Michigan, Ann Arbor, MI, p 77-83

Hedrick DB, Peacock AD, White DC (2007) Lipid analyses for viable microbial biomass, community composition, metabolic status, and in situ metabolism. In: Hurst CJ, Crawford RL, Garland JL, Lipson DA, Mills AL, Stetzenbach LD (eds) Manual of environmental microbiology, 3rd edn. ASM Press, Washington, DC, p 112-125

Hesham AEL, Khan S, Liu X, Zhang Y, Wang Z, Yang M (2006) Application of PCR-DGGE to analyse the yeast population dynamics in slurry reactors during degradation of polycyclic aromatic hydrocarbons in weathered oil. Yeast 23:879-887

Hickey P, Swift S, Roca M, Read N (2004) Live-cell imaging of filamentous fungi using vital fluorescent dyes and confocal microscopy. Method Microbiol 34:63-87

Hodkinson M (1976) Interactions between aquatic fungi and DDT. In: Jones E (ed) Recent advances in aquatic mycology. Elek Science, London, p 447-467

Hofrichter M, Fritsche W (1996) Depolymerization of lowrank coal by extracellular fungal enzyme systems. Appl Microbiol Biotechnol 46:220-225

> Hofrichter M, Fritsche W (1997) Depolymerization of lowrank coal by extracellular fungal enzyme systems. III. In vitro depolymerization of coal humic acids by a crude preparation of manganese peroxidase from the white-rot fungus Nematoloma frowardii. Appl Microbiol Biotechnol 47:566-571

Holfeld H (1998) Fungal infections of the phytoplankton: seasonality, minimal host density, and specificity in a mesotrophic lake. New Phytol 138:507-517

Howe M, Suberkropp K (1993) Effects of mycoparasitism on an aquatic hyphomycete growing on leaf litter. Mycologia 85:898-901

> Hyde K, Goh T (1998) Fungi on submerged wood in Lake Barrine, north Queensland, Australia. Mycol Res 102:739-749

Hynes HBN (1971) The biology of polluted waters. University of Toronto Press, Toronto

> Ibelings BW, Bruin AD, Kagami M, Rijkeboer M, Brehm M, Donk EV (2004) Host parasite interactions between freshwater phytoplankton and chytrid fungi (Chytridiomycota). J Phycol 40:437-453

Inacio J, Behrens S, Fuchs BM, Fonseca A, Spencer-Martins I, Amann R (2003) In situ accessibility of Saccharomyces cerevisiae 26S rRNA to Cy3-labeled oligonucleotide probes comprising the D1 and D2 domains. Appl Environ Microbiol 69:2899-2905

Jaeckel P, Krauss G, Menge S, Schierhorn A, Rücknagel P, Krauss GJ (2005) Cadmium induces a novel metallothionein and phytochelatin 2 in an aquatic fungus. Biochem Biophys Res Commun 333:150-155

Jain R, Kapur M, Labana S, Lal B, Sarma P, Bhattacharya D, Thakur I (2005) Microbial diversity: application of microorganisms for the biodegradation of xenobiotics. Curr Sci 89:101-112

James TY, Kauff F, Schoch CL, Matheny PB, and others (2006) Reconstructing the early evolution of fungi using a sixgene phylogeny. Nature 443:818-822

Jiang C, Xu L (1996) Diversity of aquatic actinomycetes in lakes of the Middle Plateau, Yunnan, China. Appl Environ Microbiol 62:249-253

> Johnson PTJ, Longcore JE, Stanton DE, Carnegie RB, Shields JD, Preu ER (2006) Chytrid infections of Daphnia puli- caria: development, ecology, pathology and phylogeny of Polycaryum laeve. Freshw Biol 51:634-648

Jones E (ed) (1976) Recent advances in aquatic mycology. Elek Science, London

Junghanns C, Moeder M, Krauss G, Martin C, Schlosser D (2005) Degradation of the xenoestrogen nonylphenol by aquatic fungi and their laccases. Microbiology 151:45-57

Junghanns C, Krauss G, Schlosser D (2008) Potential of aquatic fungi derived from diverse freshwater environments to decolourise synthetic azo and anthraquinone dyes. Bioresour Technol 99:1225-1235

Kagami M, van Donk E, de Bruin A, Rijkeboer M, Ibelings B (2004) Daphnia can protect diatoms from fungal parasitism. Limnol Oceanogr 49:680-685

Kagami M, de Bruin A, Ibelings B, van Donk E (2007) Parasitic chytrids: their effects on phytoplankton communities and food-web dynamics. Hydrobiologia 578:113-129

Kai W, Zhiwei Z (2006) Occurrence of arbuscular mycorrhizas and dark septate endophytes in hydrophytes from lakes and streams in southwest China. Int Rev Hydrobiol 91: 29-37

- Kempf VAJ, Trebesius K, Autenrieth IB (2000) Fluorescent in situ hybridization allows rapid identification of microorganisms in blood cultures. J Clin Microbiol 38:830-838

Klein DA, Paschke MW (2004) Filamentous fungi: the indeterminate lifestyle and microbial ecology. Microb Ecol 47: 224-235

Kolo KE, Keppens AP, Claeys P (2007) Experimental observations on fungal diagenesis of carbonate substrates. J Geophys Res 112, G01007, doi:10.1029/2006JG000203

Krauss G, Sridhar K, Bärlocher F (2005) Aquatic hyphomycetes and leaf decomposition in contaminated groundwater wells in central Germany. Arch Hydrobiol 162: 416-429

Kuehn KA (2008) The role of fungi in the decomposition of emergent wetland plants. In: Sridhar KR, Bärlocher F, Hyde KD (eds) Novel techniques and ideas in mycology, Vol 20, Fungal Diversity Research Series, p 19-41

Kuehn KA, Churchill PF, Suberkropp K (1998) Osmoregulatory responses of fungi inhabiting standing litter of the freshwater emergent macrophyte Juncus effusus. Appl Environ Microbiol 64:607-612

Kuehn KA, Gessner M, Wetzel R, Suberkropp K (1999) Decomposition and $\mathrm{CO}_{2}$ evolution from standing litter of the emergent macrophyte Erianthus giganteus. Microb Ecol 38:50-57

Kuehn KA, Lemke MJ, Suberkropp K, Wetzel RG (2000) Microbial biomass and production associated with decaying leaf litter of the emergent macrophyte Juncus effusus. Limnol Oceanogr 45:862-870

Kuehn KA, Steiner D, Gessner MO (2004) Diel mineralization patterns of standing-dead plant litter: implications for $\mathrm{CO}_{2}$ flux from wetlands. Ecology 85:2504-2518

Kulikova N, Suturin A, Boiko S, Lishtva A and others (2008) Original data on the diversity, ecology, and chemical composition of aquatic and semiaquatic lichens (Lichenes) of the stony littoral of Lake Baikal. Contemp Probl Ecol $1: 316-321$

> Lachance M (2003) The Phaff school of yeast ecology. Int Microbiol 6:163-167

> Lefèvre E, Bardot C, Noel C, Carrias J, Viscogliosi E, Amblard C, Sime-Ngando T (2007) Unveiling fungal zooflagellates as members of freshwater picoeukaryotes: evidence from a molecular diversity study in a deep meromictic lake. Environ Microbiol 9:61-71

> Lefèvre E, Roussel B, Amblard C, Sime-Ngando T (2008) The molecular diversity of freshwater picoeukaryotes reveals 
high occurrence of putative parasitoids in the plankton. PLoS ONE 3:e2324, doi:10.1371/journal.pone.0002324

Lefranc M, Thenot A, Lepère U, Debroas D (2005) Genetic diversity of small eukaryotes in lakes differing by their trophic status. Appl Environ Microbiol 71:5935-5942

Lepère C, Boucher D, Jardillier L, Domaizon I, Debroas D (2006) Succession and regulation factors of small eukaryote community composition in a lacustrine ecosystem (Lake Pavin). Appl Environ Microbiol 72:2971-2981

Lepère C, Domaizon I, Debroas D (2007) Community composition of lacustrine small eukaryotes in hyper-eutrophic conditions in relation to top-down and bottom-up factors. FEMS Microbiol Ecol 61:483-495

- Lepère C, Domaizon I, Debroas D (2008) Unexpected importance of potential parasites in the composition of the freshwater small-eukaryote community. Appl Environ Microbiol 74:2940-2949

Li S, Spear R, Andrews J (1997) Quantitative fluorescence in situ hybridization of Aureobasidium pullulans on microscope slides and leaf surfaces. Appl Environ Microbiol 63: 3261-3267

Libkind D, Brizzio S, Ruffini A, Gadanho M, van Broock M, Sampaio J (2003) Molecular characterization of carotenogenic yeasts from aquatic environments in Patagonia, Argentina. Ant van Leeuw Int J Microb 84:313-322

Libkind D, Diéguez MC, Moliné M, Pérez P, Zagarese HE, Broock M (2006) Occurrence of photoprotective compounds in yeasts from freshwater ecosystems of northwestern Patagonia (Argentina). Photochem Photobiol 82: 972-980

Lichtwardt R (2004) Trichomycetes: fungi in relationship with insects and other arthropods. In: Seckbach J (ed) Symbiosis mechanisms and model systems, cellular origin, life in extreme habitats and astrobiology, Vol 4. Kluwer Academic Publishers, Dordrecht, p 575-588

Ludwig W, Strunk O, Westram R, Richter L, and others (2004) ARB: a software environment for sequence data. Nucleic Acids Res 32:1363-1371

Luni H (1933) Effect of weathering upon composition of hardwood leaves. J For 31:43-45

Luo J, Yin J, Cai L, Zhang K, Hyde K (2004) Freshwater fungi in Lake Dianchi, a heavily polluted lake in Yunnan, China. Fungal Divers 16:93-112

> Luo Q, Krumholz LR, Najar FZ, Peacock AD, Roe BA, White DC, Elshahed MS (2005) Diversity of the microeukaryotic community in sulfide-rich Zodletone Spring (Oklahoma). Appl Environ Microbiol 71:6175-6184

Lutzoni F, Kauff F, Cox CJ, McLaughlin D and others (2004) Assembling the fungal tree of life: progress, classification, and evolution of subcellular traits. Am J Bot 91:1446-1480

Lyons J, Newell S, Buchan A, Moran M (2003) Diversity of ascomycete laccase gene sequences in a southeastern US salt marsh. Microb Ecol 45:270-281

MacGillivray AR, Shiaris MP (1993) Biotransformation of polycyclic aromatic hydrocarbons by yeasts isolated from coastal sediments. Appl Environ Microbiol 59:1613-1618

Mallea M (1992) Fungi from a Mediterranean salt-pan. Bot Mar 35:283-290

Mancinelli G, Costantini M, Rossi L (2002) Cascading effects of predatory fish exclusion on the detritus-based food web of a lake littoral zone (Lake Vico, central Italy). Oecologia 133:402-411

Mancinelli G, Costantini ML, Rossi L (2007) Top-down control of reed detritus processing in a lake littoral zone: experimental evidence of a seasonal compensation between fish and invertebrate predation. Int Rev Hydrobiol 92:117-134 Manerkar M, Seena S, Bärlocher F (2008) Q-RT-PCR for assessing archaea, bacteria, and fungi during leaf decomposition in a stream. Microb Ecol 56:467-473

Marshall M, Gull K, Jeffries P (1997) Monoclonal antibodies as probes for fungal wall structure during morphogenesis. Microbiology 143:2255-2265

Martin C, Moeder M, Daniel X, Krauss G, Schlosser D (2007) Biotransformation of the polycyclic musks HHCB and AHTN and metabolite formation by fungi occurring in freshwater environments. Environ Sci Technol 41: 5395-5402

> Mason C, Bryant R (1975) Production, nutrient content and decomposition of Phragmites communis Trin. and Typha angustifolia L. J Ecol 63:71-95

> Massaccesi G, Romero M, Cazau M, Bucsinszky A (2002) Cadmium removal capacities of filamentous soil fungi isolated from industrially polluted sediments, in La Plata (Argentina). World J Microb Biot 18:817-820

Masters M (1971) The occurrence of Chytridium marylandicum on Botryococcus braunii in School Bay of the Delta Marsh. Can J Bot 49:1479-1485

Masters M (1976) Freshwater phycomycetes on algae. In: Jones E (ed) Recent advances in aquatic mycology. Elek Science, London, p 489-512

McArthur FA, Baerlocher MO, MacLean NA, Hiltz MD, Bärlocher F (2001) III. Methods in litter breakdown asking probing questions: can fluorescent in situ hybridization identify and localise aquatic hyphomycetes on leaf litter? Int Rev Hydrobiol 86:429-438

McInnes S (2003) A predatory fungus (hyphomycetes: Lecophagus) attacking rotifera and tardigrada in maritime Antarctic lakes. Polar Biol 26:79-82

> Medeiros A, Kohler L, Hamdan J, Missagia B, Barbosa F, Rosa C (2008) Diversity and antifungal susceptibility of yeasts from tropical freshwater environments in southeastern Brazil. Water Res 42:3921-3929

> Medeiros AO, Pascoal C, Graça MAS (2009) Diversity and activity of aquatic fungi under low oxygen conditions. Freshw Biol 54:142-149

Miao S, Nauwerck A (1999) Fungal infection of Eudiaptomus gracilis (Copepoda, crustacea) in Lake Mondsee. Limnologica 29:168-173

Millard P, Roth B, Thi H, Yue S, Haugland R (1997) Development of the FUN-1 family of fluorescent probes for vacuole labeling and viability testing of yeasts. Appl Environ Microbiol 63:2897-2905

> Mille-Lindblom C, von Wachenfeldt E, Tranvik LJ (2004) Ergosterol as a measure of living fungal biomass: persistence in environmental samples after fungal death. J Microbiol Methods 59:253-262

> Mille-Lindblom C, Fischer H, Tranvik LJ (2006a) Litter-associated bacteria and fungi: a comparison of biomass and communities across lakes and plant species. Freshw Biol 51:730-741

> Mille-Lindblom C, Fischer H, Tranvik LJ (2006b) Antagonism between bacteria and fungi: substrate competition and a possible tradeoff between fungal growth and tolerance towards bacteria. Oikos 113:233-242

Mills C, Child J, Spencer J (1971) The utilization of aromatic compounds by yeasts. Antonie van Leeuwenhoek 37: 281-287

Mills D, Johannsen E, Cocolin L (2002) Yeast diversity and persistence in botrytis-affected wine fermentations. Appl Environ Microbiol 68:4884-4893

> Mishra R, Tiwari B (1983) Fungi and bacteria associated with pine (Pinus kesiya Royle) needles and teak (Tectona grandis $\mathrm{L}$ ) leaf litters during processing in a fresh-water lake. Hydrobiologia 102:123-129 
Mitchell JI, Zuccaro A (2006) Sequences, the environment and fungi. Mycologist 20:62-74

Mitsch W, Gosselink J (2000) Wetlands, 3rd edn. Wiley, New York

- Miyata N, Tani Y, Sakata M, Iwahori K (2007) Microbial manganese oxide formation and interaction with toxic metal ions. J Biosci Bioeng 104:1-8

- Moran M, Hodson R (1990) Contributions of degrading Spartina alterniflora lignocellulose to the dissolved organic carbon pool of a salt marsh. Mar Ecol Prog Ser 62:161-168

Morris J, Lajtha K (1986) Decomposition and nutrient dynamics of litter from four species of freshwater emergent macrophytes. Hydrobiologia 131:215-223

> Mueller GM, Schmit J (2007) Fungal biodiversity: What do we know? What can we predict? Biodivers Conserv 16:1-5

> Müller G, Nkusi G, Schöler H (1996) Natural organohalogens in sediments. J Prak Chem Chem Ztg 338:23-29

Müncnerová D, Augustin J (1994) Fungal metabolism and detoxification of polycyclic aromatic hydrocarbons: a review. Bioresour Technol 48:97-106

- Nechwatal J, Wielgoss A, Mendgen K (2008) Diversity, host, and habitat specificity of oomycete communities in declining reed stands (Phragmites australis) of a large freshwater lake. Mycol Res 112:689-696

> Neubert K, Mendgen K, Brinkmann H, Wirsel S (2006) Only a few fungal species dominate highly diverse mycofloras associated with the common reed. Appl Environ Microbiol 72:1118-1128

Newell SY (1993) Decomposition of shoots of a salt-marsh grass: methodology and dynamics of microbial assemblages. Adv Microb Ecol 13:301-326

$>$ Newell SY (1996) Established and potential impacts of eukaryotic mycelial decomposers in marine/terrestrial ecotones. J Exp Mar Biol Ecol 200:187-206

Newell SY, Fallon R (1989) Litterbags, leaf tags, and decay of nonabscised intertidal leaves. Can J Bot 67:2324-2327

- Newell SY, Hicks R (1982) Direct-count estimates of fungal and bacterial biovolume in dead leaves of smooth cordgrass (Spartina alterniflora Loisel.). Estuaries Coasts 5:246-260

Newell SY, Fallon RD, Miller JD (1989) Decomposition and microbial dynamics for standing, naturally positioned leaves of the salt-marsh grass Spartina alterniflora. Mar Biol 101:471-481

- Newell SY, Moran MA, Wicks R, Hodson RE (1995) Productivities of microbial decomposers during early stages of decomposition of leaves of a freshwater sedge. Freshw Biol 34:135-148

> Nikolcheva L, Bärlocher F (2004) Taxon-specific fungal primers reveal unexpectedly high diversity during leaf decomposition in a stream. Mycol Prog 3:41-49

Nikolcheva LG, Bärlocher F (2005) Seasonal and substrate preferences of fungi colonizing leaves in streams: traditional versus molecular evidence. Environ Microbiol 7: $270-280$

- Nikolcheva L, Cockshutt A, Bärlocher F (2003) Determining diversity of freshwater fungi on decaying leaves: comparison of traditional and molecular approaches. Appl Environ Microbiol 69:2548-2554

> Nikolcheva LG, Bourque T, Bärlocher F (2005) Fungal diversity during initial stages of leaf decomposition in a stream. Mycol Res 109:246-253

Nilsson S (1964) Freshwater hyphomycetes — taxonomy, morphology and ecology. Symb Bot Ups XVIII:2

> Nosanchuk JD, Casadevall A (2003) The contribution of melanin to microbial pathogenesis. Cell Microbiol 5:203-223

Orlowska M, Lengiewicz I, Suszycka M (2004) Hyphomycetes developing on water plants and bulrushes in fish ponds.
Pol J Environ Stud 13:703-707

Ortiz-Bermúdez P, Hirth KC, Srebotnik E, Hammel KE (2007) Chlorination of lignin by ubiquitous fungi has a likely role in global organochlorine production. Proc Natl Acad Sci USA 104:3895-3900

Pabst S, Scheifhacken N, Hesselschwerdt J, Wantzen K (2008) Leaf litter degradation in the wave impact zone of a prealpine lake. Hydrobiologia 613:117-131

Park D (1972) On the ecology of heterotrophic microorganisms in freshwater. Trans Br Mycol Soc 58:291-299

Pascoal C, Cássio F (2008) Linking fungal diversity to the functioning of freshwater ecosystems. In: Sridhar KR, Bärlocher F, Hyde KD (eds) Novel techniques and ideas in mycology, Vol 20, Fungal Diversity Research Series, p 1-19

Perez-Osorio AC, Franklin MJ (2008) qRT-PCR of microbial biofilms. Cold Spring Harbor Protoc 2008 doi:10.1101/ pdb.prot5066

Polunin NVC (1984) The decomposition of emergent macrophytes in fresh water. In: MacFadyen A, Ford ED (eds) Advances in ecological research, Vol 14. Academic Press, New York, p 115-166

> Powell M (1993) Looking at mycology with a Janus face: a glimpse at chytridiomycetes active in the environment. Mycologia 85:1-20

Prenafeta-Boldu F, Summerbell R, De Hoog G (2006) Fungi growing on aromatic hydrocarbons: biotechnology's unexpected encounter with biohazard? FEMS Microbiol Rev 30:109-130

> Preston N, Carpenter S, Cole J, Pace M (2008) Airborne carbon deposition on a remote forested lake. Aquat Sci 70: 213-224

Pruesse E, Quast C, Knittel K, Fuchs BM, Ludwig W, Peplies J, Glockner FO (2007) SILVA: a comprehensive online resource for quality checked and aligned ribosomal RNA sequence data compatible with ARB. Nucleic Acids Res 35:7188-7196

Pugh G, Mulder J (1971) Mycoflora associated with Typha latifolia. Trans Br Mycol Soc 57:273-282

Rachini A, Pietrella D, Lupo P, Torosantucci A and others (2007) An anti-beta-glucan monoclonal antibody inhibits growth and capsule formation of Cryptococcus neoformans in vitro and exerts therapeutic, anticryptococcal activity in vivo. Infect Immun 75:5085-5094

Rasconi S, Jobard M, Jouve L, Sime-Ngando T (2009) Use of Calcofluor White for detection, identification, and quantification of phytoplanktonic fungal parasites. Appl Environ Microbiol 75:2545-2553

Raviraja N, Nikolcheva L, Bärlocher F (2005) Diversity of conidia of aquatic hyphomycetes assessed by microscopy and by DGGE. Microb Ecol 49:301-307

> Reisert P, Fuller M (1962) Decomposition of chitin by chytriomyces species. Mycologia 54:647-657

> Robin J, Arffa R, Avni I, Rao N (1986) Rapid visualization of three common fungi using fluorescein-conjugated lectins. Invest Ophthalmol Vis Sci 27:500-506

> Röder C, König H, Fröhlich J (2007) Species-specific identification of Dekkera brettanomyces yeasts by fluorescently labeled DNA probes targeting the 26S rRNA. FEM Yeast Res 7:1013-1026

Rodrigues G (2001) Benthic fauna of extremely acidic lakes (pH 2-3). PhD thesis, Universität Carolo-Wilhelmina, Braunschweig

> Romani AM, Fischer H, Mille-Lindblom C, Tranvik LJ (2006) Interactions of bacteria and fungi on decomposing litter: differential extracellular enzyme activities. Ecology 87: $2559-2569$ 
Romero S, Blánquez P, Caminal G, Font X, Sarrà M, Gabarrell X, Vicent T (2006) Different approaches to improving the textile dye degradation capacity of Trametes versicolor. Biochem Eng J 31:42-47

Rosa CA, Gabor P (eds) (2006) Biodiversity and ecophysiology of yeasts, 1st edn. Springer, Berlin

Rosa C, Resende M, Barbosa F, Morais P, Franzot S (1995) Yeast diversity in a mesotrophic lake on the karstic plateau of Lagoa Santa, Mg-Brazil. Hydrobiologia 308: 103-108

Russo G, Libkind D, Sampaio JP, van Broock MR (2008) Yeast diversity in the acidic Rio Agrio-Lake Caviahue volcanic environment (Patagonia, Argentina). FEMS Microbiol Ecol 65:415-424

Samiaji J, Bärlocher F (1996) Geratology and decomposition of Spartina alterniflora Loisel in a New Brunswick saltmarsh. J Exp Mar Biol Ecol 201:233-252

Sampaio A, Sampaio JP, Leão C (2007) Dynamics of yeast populations recovered from decaying leaves in a nonpolluted stream: a 2-year study on the effects of leaf litter type and decomposition time. FEM Yeast Res 7:595-603

Schadt CW, Martin AP, Lipson DA, Schmidt SK (2003) Seasonal dynamics of previously unknown fungal lineages in tundra soils. Science 301:1359-1361

Schindler DE, Scheuerell MD (2002) Habitat coupling in lake ecosystems. Oikos 98:177-189

Schmid M, Selesi D, Rothballer M, Schloter M, Lee N, Kandeler E, Hartmann A (2006) Localization and visualization of microbial community structure and activity in soil microhabitats. In: Konig H, Varma A (eds) Intestinal microorganisms of termites and other invertebrates, soil biology, Vol 6. Springer, Berlin, p 439-461

Schüßler A, Bonfante P, Schnepf E, Mollenhauer D, Kluge M (1996) Characterization of the Geosiphon pyriforme symbiosome by affinity techniques: confocal laser scanning microscopy (CLSM) and electron microscopy. Protoplasma 190:53-67

Scupham AJ, Presley LL, Wei B, Bent E and others (2006) Abundant and diverse fungal microbiota in the murine intestine. Appl Environ Microbiol 72:793-801

Seena S, Wynberg N, Bärlocher F (2008) Fungal diversity during leaf decomposition in a stream assessed through clone libraries. Fungal Divers 30:1-14

Sekar R, Pernthaler A, Pernthaler J, Warnecke F, Posch T, Amann R (2003) An improved protocol for quantification of freshwater actinobacteria by fluorescence in situ hybridization. Appl Environ Microbiol 69:2928-2935

Shearer C, Descals E, Kohlmeyer B, Kohlmeyer J and others (2007) Fungal biodiversity in aquatic habitats. Biodivers Conserv 16:49-67

Shimoyama T, Kato S, Ishii S, Watanabe K (2009) Flagellum mediates symbiosis. Science 323:1574

Sigee D (2005) Freshwater microbiology: biodiversity and dynamic interactions of microorganisms in the aquatic environment. John Wiley \& Sons, Chichester

> Slapeta J, Moreira D, López-Garcia P (2005) The extent of protist diversity: insights from molecular ecology of freshwater eukaryotes. Proc Roy Soc B Biol Sci 272: 2073-2081

Slavikova E, Vadkertiova R, Kockovakratochvilova A (1992) Yeasts isolated from artificial lake waters. Can J Microbiol 38:1206-1209

Smirnov NN (1961) Food cycles in sphagnous bogs. Hydrobiologia 17:175-182

Smirnov NN (1964) On the quantity of allochthonous pollen and spores received by the Rybinsk Reservoir. Hydrobiologia 24:421-429

Soeder CJ, Maiweg D (1969) Einfluss pilzlicher Parasiten auf unsterile Massenkulturen von Scenedesmus. Arch Hydrobiol 66:48-55

Solé M, Chatzinotas A, Sridhar K, Harms H, Krauss G (2008) Improved coverage of fungal diversity in polluted groundwaters by semi-nested PCR. Sci Total Environ 406:324-330

> Sommerstorff H (1911) Ein Tiere fangender Pilz. Plant Syst Evol 61:361-373

Sparrow F (1960) Aquatic phycomycetes, 2nd edn. University of Michigan Press, Ann Arbor, MI

Sparrow F (1968) Ecology of freshwater fungi. In: Ainsworth G, Sussman A (eds) The fungi-an advanced treatise, The fungal population, Vol 3. Academic Press, New York, p 41-93

Spear R, Li S, Nordheim E, Andrews J (1999) Quantitative imaging and statistical analysis of fluorescence in situ hybridization (FISH) of Aureobasidium pullulans. J Microbiol Methods 35:101-110

Steffen KT, Hatakka A, Hofrichter M (2002) Degradation of humic acids by the litter-decomposing basidiomycete Collybia dryophila. Appl Environ Microbiol 68:3442-3448

Steiman R, Ford L, Ducros V, Lafond J, Guiraud P (2004) First survey of fungi in hypersaline soil and water of Mono Lake area (California). Ant van Leeuw Int J Microb 85:69-83

Steinberg C (2008) Humic substances in the environment with an emphasis on freshwater systems. Environ Sci Pollut R 15:15-16

Suberkropp K (2008) Fungal biomass and growth. In: Sridhar KR, Bärlocher F, Hyde K (eds) Novel ideas and techniques in mycology. Fungal Diversity Research Series 20:203-213

- Takano K, Itoh Y, Ogino T, Kurosawa K, Sasaki K (2006) Phylogenetic analysis of manganese-oxidizing fungi isolated from manganese-rich aquatic environments in Hokkaido, Japan. Limnology 7:219-223

Takishita K, Tsuchiya M, Kawato M, Oguri K, Kitazato H, Maruyama T (2007) Genetic diversity of microbial eukaryotes in anoxic sediment of the saline meromictic Lake Namako-ike (Japan): on the detection of anaerobic or anoxic-tolerant lineages of eukaryotes. Protist 158:51-64

- Takizawa M, Colwell RR, Hill RT (1993) Isolation and diversity of actinomycetes in the Chesapeake Bay. Appl Environ Microbiol 59:997-1002

Tang KW, Hutalle KML, Grossart HP (2006) Microbial abundance, composition and enzymatic activity during decomposition of copepod carcasses. Aquat Microb Ecol 45: $219-227$

- Teal JM (1962) Energy flow in the salt marsh ecosystem of Georgia. Ecology 43:614-624

Thormann M (2006) The role of fungi in boreal peatlands. In: Caldwell MM, Heldmaier G, Jackson RB, Lange OL, Mooney HA, Jena EDS, Sommer U (eds) Boreal peatland ecosystems, ecological studies, Vol 188. Springer, Berlin, p 101-123

Thormann M, Rice A, Beilman D (2007) Yeasts in peatlands: a review of richness and roles in peat decomposition. Wetlands 27:761-772

Tong Y, Lin G, Ke X, Liu F, Zhu G, Gao G, Shen J (2005) Comparison of microbial community between two shallow freshwater lakes in middle Yangtze basin, east China. Chemosphere 60:85-92

Torzilli AP, Sikaroodi M, Chalkley D, Gillevet PM (2006) A comparison of fungal communities from four salt marsh plants using automated ribosomal intergenic spacer analysis (ARISA). Mycologia 98:690-698

Tubaki K (1973) Aquatic sediment as a habitat of Emericellopsis, with a description of an undescribed species of Cephalosporium. Mycologia 65:938-941

Urich T, Lanzén A, Qi J, Huson DH, Schleper C, Schuster SC 
(2008) Simultaneous assessment of soil microbial community structure and function through analysis of the metatranscriptome. PLoS ONE 3:e2527, doi:10.1371/journal. pone. 0002527

van Donk E, Bruning K (1992) Ecology of aquatic fungi in and on algae. In: Reisser W (ed) Algae and symbioses. Biopress, Bristol, p 567-592

van Donk E, Bruning K (1995) Effects of fungal parasites on planktonic algae and the role of environmental factors in the fungus-alga relationship. In: Wiessner W, Schnepf E, Starr RC (eds) Algae, environment and human affairs. Biopress, Bristol, p 223-234

van Donk E, Ringelberg J (1983) The effect of fungal parasitism on the succession of diatoms in Lake Maarsseveen I (The Netherlands). Freshw Biol 13:241-251

van Hannen E, Mooij W, van Agterveld M, Gons H, Laanbroek H (1999) Detritus-dependent development of the microbial community in an experimental system: qualitative analysis by denaturing gradient gel electrophoresis. Appl Environ Microbiol 65:2478-2484

van Ryckegem G, Gessner M, Verbeken A (2007) Fungi on leaf blades of Phragmites australis in a brackish tidal marsh: diversity, succession, and leaf decomposition. Microb Ecol 53:600-611

van Uden N, Ahearn DC (1963) Occurrence and population densities of yeast species in a fresh-water lake. Antonie van Leeuwenhoek 29:308-312

Venrecchia E (2000) Fungi and sediments. In: Robert R, Awramik S (eds) Microbial sediments. Springer, Berlin, Heidelberg, p 68-75

Wainwright M (2005) Oligotrophic growth of fungi. In: Dighton J, White JF, Oudemans P (eds) The fungal community: its organization and role in the ecosystem, Vol 23, 3rd edn. Taylor \& Francis Group, Boca Raton, FL, p 643-658

Weber SD, Hofmann A, Pilhofer M, Wanner G and others (2009) The diversity of fungi in aerobic sewage granules assessed by $18 \mathrm{~S}$ rRNA gene and ITS sequence analyses. FEMS Microbiol Ecol 68:246-254

Webster JR, Benfield EF (1986) Vascular plant breakdown in freshwater ecosystems. Annu Rev Ecol Syst 17:567-594

Webster J, Descals E (1981) Morphology, distribution, and ecology of conidial fungi in freshwater habitats. In: Cole GC, Kendrick B (eds) Biology of conidial fungi, Vol 1. Academic Press, London, p 295-355

Westlake DF (1963) Comparisons of plant productivity. Biol Rev Camb Philos Soc 38:385-425

Editorial responsibility: Lars Tranvik, Uppsala, Sweden
Wetzel RG (1990) Land-water interfaces: metabolic and limnological regulators. Verh Internat Ver Limnol 24:6-24

Whisler HC, Zebold SL, Shemanchuk JA (1975) Life history of Coelomomyces psorophorae. Proc Natl Acad Sci USA 72:693-696

Widenfalk A, Bertilsson S, Sundh I, Goedkoop W (2008) Effects of pesticides on community composition and activity of sediment microbes - responses at various levels of microbial community organization. Environ Pollut 152: $576-584$

Willoughby LG (1969) A study of the aquatic actinomycetes of Blelham Tarn. Hydrobiologia 34:465-483

Willoughby LG (1983) A new kind of antagonistic association, between bacteria and aquatic fungi. Trans Br Mycol Soc 80:91-97

Wirsel S, Leibinger W, Ernst M, Mendgen K (2001) Genetic diversity of fungi closely associated with common reed. New Phytol 149:589-598

Wohl DL, McArthur JV (1998) Actinomycete-flora associated with submersed freshwater macrophytes. FEMS Microbiol Ecol 26:135-140

Wohl DL, McArthur JV (2001) Aquatic actinomycete-fungal interactions and their effects on organic matter decomposition: a microcosm study. Microb Ecol 42:446-457

Wong MK, Goh TK, Hodgkiss IJ, Hyde KD and others (1998) Role of fungi in freshwater ecosystems. Biodivers Conserv 7:1187-1206

Woollett L, Hedrick L (1970) Ecology of yeasts in polluted water. Antonie van Leeuwenhoek 36:427-435

- Yachi S, Loreau M (1999) Biodiversity and ecosystem productivity in a fluctuating environment: the insurance hypothesis. Proc Natl Acad Sci USA 96:1463-1468

Zalar P, de Hoog G, Gunde-Cimerman N (1999) Ecology of halotolerant dothideaceous black yeasts. Stud Mycol 43:38-48

Zalar P, Kocuvan MA, Plemenitaš A, Gunde-Cimerman N (2005) Halophilic black yeasts colonize wood immersed in hypersaline water. Bot Mar 48:323-326

Zemek J, Marvanová L, Kuniak L, Kadlečíková B (1985) Hydrolytic enzymes in aquatic hyphomycetes. Folia Microbiol (Praha) 30:363-372

Zopf W (1884) Zur Kenntniss der Phycomyceten-Zur Morphologie und Biologie der Ancylisteen und Chytridiaceen zugleich ein Beitrag zur Phytopathologie, Vol 47. Nova Acta der Kaiserlichen Leopoldino-Carolinischen Deutschen Akademie der Naturforscher, Halle

Submitted: June 18, 2009; Accepted: October 16, 2009

Proofs received from author(s): March 19, 2010 